
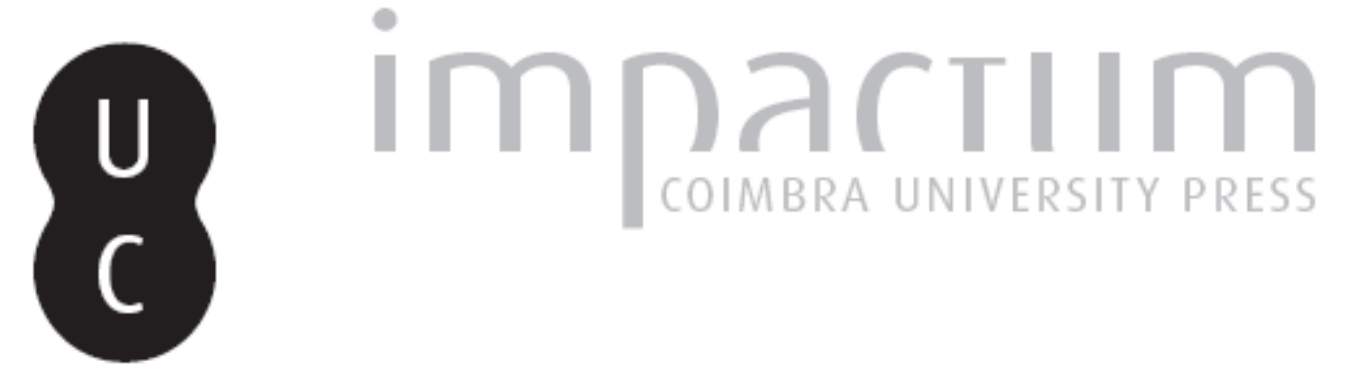

\title{
Abordagem histórico-artística a dois manuscritos litúrgicos do scriptorium do Mosteiro de Alcobaça do último quartel do século XII ou o início de "huma livraria copiosa"
}
Autor(es):
Barreira, Catarina Fernandes
Publicado por: Imprensa da Universidade de Coimbra
URL
persistente:
URI:http://hdl.handle.net/10316.2/43326
DOI:
DOI:https://doi.org/10.14195/1645-2259_17_2

\section{Accessed : $\quad$ 26-Apr-2023 11:47:36}

A navegação consulta e descarregamento dos títulos inseridos nas Bibliotecas Digitais UC Digitalis, UC Pombalina e UC Impactum, pressupõem a aceitação plena e sem reservas dos Termos e Condições de Uso destas Bibliotecas Digitais, disponíveis em https://digitalis.uc.pt/pt-pt/termos.

Conforme exposto nos referidos Termos e Condições de Uso, o descarregamento de títulos de acesso restrito requer uma licença válida de autorização devendo o utilizador aceder ao(s) documento(s) a partir de um endereço de IP da instituição detentora da supramencionada licença.

Ao utilizador é apenas permitido o descarregamento para uso pessoal, pelo que o emprego do(s) título(s) descarregado(s) para outro fim, designadamente comercial, carece de autorização do respetivo autor ou editor da obra.

Na medida em que todas as obras da UC Digitalis se encontram protegidas pelo Código do Direito de Autor e Direitos Conexos e demais legislação aplicável, toda a cópia, parcial ou total, deste documento, nos casos em que é legalmente admitida, deverá conter ou fazer-se acompanhar por este aviso.

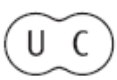




\section{Abordagem histórico-artística a dois manuscritos litúrgicos do scriptorium do Mosteiro de Alcobaça do último quartel do século XII ou o início de "huma livraria copiosa”}

\section{Historical-artistic approach to two liturgical manuscripts of the scriptorium of the Monastery of Alcobaça from the last quarter of the twelfth century or the beginning of "a copious bookstore"}

\section{Catarina Fernandes Barreira ${ }^{1}$}

Instituto de Estudos Medievais - FCSH - Universidade Nova de Lisboa cbarreira@fcsh.unl.pt

Texto recebido em/Text submitted on: 05/11/2016 Texto aprovado em /Text approved on: 06/03/2017

Resumo: Neste artigo é nossa intenção estudar dois manuscritos litúrgicos iluminados, um Coletário-ritual (Alc. 166) e um Saltério-hinário (Alc. 11), produzidos no scriptorium de Alcobaça em finais do séc. XII. A análise do seu conteúdo litúrgico e da decoração iluminada, a par com a comparação com outros manuscritos oriundos do mesmo mosteiro, permitirão afinar a sua datação e confirmar a sua origem alcobacense e o seu contexto de produção.

Palavras-chave: Alcobaça, Liturgia, Manuscrito, Scriptorium, Iluminuras.

Abstract: This article aims to study two illuminated liturgical manuscripts from the monastic library of Alcobaça, a Collectary - ritual (Alc. 166) and a Psalter-hymnal (Alc. 11), both from the late twelfth century. The analysis of its liturgical contents and illuminated decorations, along with its comparison with other illuminated manuscripts from the same monastery, intends to accurate their context and dates of production and their origin in this Cistercian house.

Keywords: Alcobaça, Liturgy, Manuscript, Scriptorium, Illumination.

\section{O scriptorium de Alcobaça no séc. XII}

A produção de manuscritos no scriptorium do Mosteiro de Alcobaça tem, nas últimas décadas, atraído a atenção dos investigadores portugueses. Destes, cumpre destacar o contributo decisivo de Aires A. Nascimento ${ }^{2}$, mas também

\footnotetext{
Bolseira de Pós-Doutoramento FCT com a refa SFRH/BPD/70067/2010.

2 Por questões de espaço, e porque a sua bibliografia para o assunto em questão é extensa, destacamos só os trabalhos que vamos mencionar neste artigo: Nascimento, 1978; Nascimento 1979; Nascimento e Diogo 1984, Nascimento 1985, Nascimento 1991, Nascimento 1992a, Nascimento 1992b, Nascimento 2012.
} 
de Adelaide Miranda, Horácio Peixeiro ${ }^{3}$, Manuel Pedro Ferreira ${ }^{4}$ e Joaquim Oliveira Bragança ${ }^{5}$, entre outros. Os trabalhos desenvolvidos por Aires A. Nascimento no campo da Codicologia e, em particular, em torno das encadernações alcobacenses (Nascimento e Diogo 1984; Nascimento 1992b; Nascimento 2012) demonstraram que o scriptorium do Mosteiro foi o local de origem da maioria dos manuscritos da sua livraria que chegaram aos nossos dias. Para além da caracterização e "identificação de um scriptorium" (Nascimento 1992b: 155), Aires A. Nascimento confirmou ainda que as orientações que estiveram na base da constituição da biblioteca de Alcobaça foram semelhantes às encontradas para outras abadias cistercienses, nomeadamente para a abadia-mãe, Claraval, apesar da forte ligação de Alcobaça com o contexto local (Nascimento 1992b: 156 e 162).

Fundado o cenóbio em abril de 1153 (Gomes 2000; Gomes 2013a), a comunidade monástica ficou instalada em acomodações provisórias: a edificação da igreja e as instalações conventuais tiveram início duas décadas e meia depois, em 1178 (Gusmão 1992: 22 e 23; Gomes 1998: 11; Gomes 2002: 207). Em 1227 está documentado um pedido do abade de Alcobaça ao Capítulo Geral para mudar a abadia, ou seja, das instalações provisórias para as novas (Marques 2008: 53), corroborando, segundo os historiadores Artur Nobre de Gusmão, Mário Barroca e Saul Gomes, uma mudança ocorrida alguns anos antes, em 1223 (Gusmão 1992: 23; Barroca 2000: 90, 130 e 157; Gomes 2002: 208 e 233). A igreja foi consagrada a 20 de outubro de 1252, pelos bispos de Lisboa e Coimbra, como ficou registado no Livro das Eras de Sta. Cruz de Coimbra (Nascimento 1992b: 161; Gomes 2000: 39; Gomes 2002: 202 e 208).

No entanto, o scriptorium de Alcobaça iniciou a produção de manuscritos iluminados ainda em finais do séc. XII, um funcionamento atestado por vários autores (Nascimento 1991: 121-145; Nascimento 1992b: 149 - 162; Miranda 1996; Guerra 2003: 226; Nascimento 2012: 292)6.

Das quase cinco centenas de manuscritos que nos chegaram $^{7}$, cerca de 19 foram identificados por Aires A. Nascimento no Índice do Inventário dos

3 No campo da história da arte, assinalamos os trabalhos de Adelaide Miranda: Miranda 1996; Miranda 2000; Miranda 2007. Nos últimos anos tem vindo a dedicar-se, com uma equipa multidisciplinar, ao estudo do mapeamento da cor nos manuscritos de Alcobaça (bem como de Sta. Cruz e Lorvão): Miranda et al 2008 e Miranda e Melo 2014. Os contributos de Horácio Peixeiro: Peixeiro 1986; Peixeiro 1991; Peixeiro 2007.

4 Este investigador é um especialista no campo dos manuscritos com notação musical: Ferreira 2009; Ferreira 2013; Ferreira e Araújo 2013.

5 No que concerne a manuscritos litúrgicos cistercienses ver Bragança 1984; Bragança 2008.

6 A propósito da produção de manuscritos em instalações provisórias, ver Suárez González 2005: 270.

7 Segundo Aires A. Nascimento, em 1775 o Index Codicum descrevia 476 códices (Nascimento 2012: 207). O Inventário dos Códices Alcobacenses em 1930/32 contabilizava 456 códices, número a que se somaram os 8 que estavam no Arquivo Nacional Torre do Tombo e que se reuniram com os da BNP, totalizando 464 (Nascimento 1979: 205-206; Nascimento 1985: 107; Nascimento 2012: 205-214 e 237). Joaquim 
Códices Alcobacenses como pertencentes ao séc. XII ${ }^{8}$ (Nascimento 1978: 523). $\mathrm{O}$ autor veio ainda juntar a este núcleo mais antigo do scriptorium de Alcobaça os cinco códices que constituem o Legendário alcobacense, datável dos finais do séc. XII (Alc. 418 a 422). Este teve como modelo o Legendário de Claraval, disponível a partir do último terço do séc. XII para circular entre abadias-filhas. No entanto, a sua recepção não foi passiva, mas o seu conteúdo foi adaptado às circunstâncias litúrgicas locais através da adição de novas entradas, relacionadas com o contexto português (Dolbeau 1984; Nascimento 1992a: 149-150; Benulic 2007; Nascimento 2012: 291 e 292).

Devem incluir-se no conjunto anterior o Alc. 238, que investigações recentes vieram datar um dos seus textos, o De Avibus, entre 1180 e 1190 (Castro et al. 2014: 37), e uma Bíblia em cinco volumes, Alc. 427 a 431 (Nascimento 1978: 523; Nascimento e Diogo 1984: 15), que Adelaide Miranda e Luís Sousa dataram como tendo sido copiada em finais do séc. XII (Miranda 2015: 34; Sousa 2016: 112). Ainda segundo Luís Sousa, de data próxima é o manuscrito Alc. 157, uma Bíblia glosada (Sousa 2016: 113).

Como tem vindo a ser demonstrado por Aires A. Nascimento, o Fundo de Alcobaça respeitante ao séc. XII também inclui manuscritos elaborados noutros scriptoria: o Alc. 143, datado de 1185, teve origem no scriptorium do Mosteiro do Lorvão, uma origem atestada pelo seu cólofon, embora se desconheça em que data passou a fazer parte da biblioteca alcobacense (Nascimento 2012: 295, 402 e seguintes; Nascimento 2016: 34).

Ao analisarmos o tipo de manuscritos do séc. XII preservados, que atinge os 32 espécimes (Anexo I), há um dado bastante evidente: só dois manuscritos se destinam diretamente ao uso litúrgico, um Coletário-ritual (Alc. 166) e um Saltério-hinário (Alc. 11). Como explicar esta ausência de manuscritos litúrgicos para o período em questão? Onde estão os primeiros manuscritos, contemporâneos da fundação de Alcobaça e necessários ao funcionamento da comunidade, como o testemunham os Capitula ${ }^{9}$ cistercienses?

Oliveira Bragança localizou um Processional- Tropário do Mosteiro, o COD. 6207 na Biblioteca Nacional (Bragança 1984). Para Manuel Pedro Ferreira o scriptorium de origem do Il. 115 foi, muito provavelmente, Alcobaça (Ferreira 2016: 319-326). Saul Gomes localizou, na Biblioteca Geral da Universidade de Coimbra, um Coletário de Alcobaça, Ms. 893 (Gomes 2013b: 430; Gomes 2009: 58). A este número somámos mais dois manuscritos: um Ordinário do Oficio Divino, hoje na Biblioteca Nacional da Austrália (Barreira 2015: 136) e um Ritual atualmente na posse da Paróquia de Salzedas (Rêpas e Barreira 2016; Barreira e Rêpas 2016).

8 Indicamos a sua cota: Alc. 11, Alc. 136, Alc. 152, Alc. 154, Alc. 166, Alc. 231, Alc. 232, Alc. 248, Alc. 332, Alc. 333, Alc. 335, Alc. 336, Alc. 357, Alc. 358, Alc. 367, Alc. 423, Alc. 424, 425 e 426 (Nascimento 1978: 523).

9 "De construendis abbatiis. VIIII. (... ) Nom mittendum esse abbatem nouum in locum nouellum sine monachis ad minus XII ${ }^{\mathrm{cim}}$, nec sine libris istis: psalterio, hymnario, collectane, antifonario, gradali, regula, missali." (Waddell 2002: 512). 
À excepção da Regra de S. Bento, o conjunto de livros necessários à fundação de novas abadias eram todos litúrgicos (Bell 2013: 140). Este "pacote-inicial" de manuscritos era geralmente oferecido pela abadia-mãe (Nascimento 1992b: 153; Jamroziak 2013: 210). Em relação a Alcobaça e aos manuscritos necessários para assegurar o funcionamento da vida monástica ${ }^{10}$, Aires A. Nascimento menciona que desapareceram os "livros primitivos para podermos comprovar se isso se verificou entre Claraval e Alcobaça, logo no início. De tempos subsequentes, porém, não restam dúvidas." (Nascimento 1991: 123). De igual modo, também Manuel Pedro Ferreira, no que concerne aos manuscritos de Alcobaça e aos seus traços paleográficos, refere que as suas particularidades tiveram como modelo os manuscritos de Claraval, o que confirma "por fontes desta última abadia, conservados na Mediateca de Troyes.” (Ferreira e Araújo 2013: 197).

Uma justificação para o desaparecimento dos livros primitivos pode estar no facto de, à semelhança do que ocorreu em Claraval, os manuscritos litúrgicos terem sido reutilizados, mais tarde, nas encadernações - o estudo e a datação dos fragmentos das encadernações dos códices alcobacenses vão decerto contar uma história da biblioteca e da produção do scriptorium de Alcobaça diferente da que hoje conhecemos.

José Mattoso chamou há muito a atenção para a concomitante escassez e pobreza da documentação do cenóbio para o séc. XII, que relaciona com "o facto de o mosteiro ter sido destruído antes de 1195 por uma incursão de sarracenos que matou grande parte dos monges ou mesmo toda a comunidade." (Mattoso 2002: 185). Esta incursão poderia ter sido responsável pela ausência dos manuscritos oferecidos por Claraval e também pela quantidade diminuta de manuscritos litúrgicos?

Sobre este tópico, Saul Gomes cita os Capítulos de 1195 e 1197 e refere que "Deve merecer acolhimento, pelos elementos mencionados, como dado histórico positivo, a notícia ou tradição alcobacense de ter sido dizimada toda ou a maior parte da comunidade religiosa local em 1195" (Gomes 2002: 223). No entanto, outros dados atestam a sobrevivência de parte dos monges alcobacenses após tal incursão: ainda segundo Saul Gomes, o abaciado de D. Mendo estendeu-se de 1191 a 1206, ano em que este viria a falecer (Gomes 2002: 229; Gomes 2012: 140); da mesma época "são também Frei Pedro Froidiz e Frei Fernando Mendes que vemos serem nomeados diversas vezes pelo papa Inocêncio III para presidir "causas gravíssimas", particularmente este último, que ascenderia à cátedra abacial em 1206..." (Gomes 2000: 48; Gomes 2002: 228).

10 "Quos libros non liceat habere diversos. X. Quos libros non licet habere diversos. Missale, epistolare, textus, collectaneum, graduale, antiphonarium, regula, psalterium, lectionarium, kalendarium, ubique uniformiter habeantur." (Canivez I 1933: 13; Waddell 2002: 513) 
Sobre a questão da invasão, Manuel Pedro Ferreira destaca, em relação a 1190, que "there is some evidence of an attack on the nearby monastery of Alcobaça during this short siege (between 5 and 11 July)" (Ferreira 2013: 301), mas que a data de 1195 para a referida incursão Almóada é improvável (Ferreira 2013: 302). E se, efetivamente, a jovem comunidade monástica sofreu danos - humanos e materiais - o seu impacto ou profundidade não podem ter sido, como referiram Maur Cocheril e José Mattoso, graves ou tão graves ao ponto de se pensar num extermínio dos monges (Cocheril, 1966; Mattoso 2002). Neste caso, se tivesse ocorrido, quer Thomas Amos, quer Manuel Pedro Ferreira sublinham que esse acontecimento decerto que era lembrado e comemorado pela Ordem (Amos I 1988: xviii; Ferreira 2013: 304 e 305). Os Statuta de 1195 fazem uma referência vaga ao assunto, reportando-se ao ano anterior: Statutum est Anno praeterito ut pro tribulatione terrae sanctae et incursu Saracenorum in Hispaniam... (Amos I 1988: xviii; Waddell 2002: 306).

Efetivamente, ao consultarmos a documentação de Alcobaça, verificamos que, para o período em questão, há um número significativo de referências ao abade D. Mendo, mencionado por Saul Gomes, e a frades do Mosteiro durante este abaciado ${ }^{11}$. E António Joaquim R. Guerra confirmou, para 1192, a existência de um scriptorium em Alcobaça (Guerra 2003: 226). Logo, parece-nos que a posição de Manuel Pedro Ferreira constitui a hipótese mais plausível, ou seja, a comunidade monástica sofreu alguns danos, mas estes não podem ter sido tão graves ao ponto de terem tido como consequência o extermínio dos monges.

\section{O Coletário-ritual Alc. $166^{12}$}

Um Coletário é, como o nome indica, um manuscrito que contém as coletas, quer as do Ofício Divino, quer as da Missa ${ }^{13}$. Neste caso, estamos perante um

11 Por questões de espaço, não vamos enumerar a documentação onde aparece o abade, mas só as referências a monges/frades de Alcobaça. T.T., Mosteiro de Alcobaça, 1. incorp. Maço 1: docs. 36 e 37, ambos de 1187, redigidos por um monge; o mesmo Pedro (que se intitula como Frater Petrus monacus) terá sido o responsável pelo doc. 40, de 1188; T.T., Mosteiro de Alcobaça, 1. incorp. Maço 2: doc. 9, de 1190, uma venda aos frades de Alcobaça, Frei Martinho notauit e foram testemunhas Fratrer Brunu e Frater Gunsalvus; doc. 18, de 1191, menciona o celeireiro Pedro Mendes e um frade, Gonçalo Soares; o doc. 22, de 1192 é uma venda aos frades de Alcobaça; o doc. 26, de 1195 dirige-se ao abade e frades; o doc. 28 datado de 1196 menciona Frei Egas, converso de Alcobaça; Saul Gomes publicou um documento de cerca de 1193, um texto fragmentário do processo judicial que opôs Sta. Cruz de Coimbra e Alcobaça, sobre os direitos desta abadia. Neste documento estão mencionados, como testemunhas do Mosteiro, quinzes monges. (Gomes 2000: 57 e 59).

12 Sobre este manuscrito ver Pereira 1996: 144; Miranda 1996: 132 e 266; Mattoso 2002: 278 e 279 e, em particular, Mattoso 2001: 65 e seguintes, Cavero Dominguez et al, 2013: 128 e seguintes. Thomas Amos atribui-lhe uma origem francesa (Amos II 1989: 33).

13 Sobre Coletários ver Pereira 1996: 144 (onde o autor menciona este coletário) e Waddell 2007: 65 e seguintes. 
Coletário para a celebração do Oficio Divino, porque contém os capitula (leituras breves) e as coletas (orações) para as horas de vesperas, laudes, prima, sexta e nona, do Próprio do Tempo e do Santoral. A coleta de laudes - específica para cada festividade - repete a coleta da missa respetiva, neste caso a primeira oração que fechava os ritos iniciais e o momento penitencial, antes das leituras bíblicas. Coletário-ritual porque a seguir às coletas do Comum dos Santos e da Dedicação da Igreja, este manuscrito integra um conjunto de orações e fórmulas rituais que vamos desenvolver mais adiante, como as orações para a entrada e saída de monges, a unção dos enfermos e as exéquias dos defuntos. Importa pois analisar a sua utilização em contexto litúrgico e no âmbito do quotidiano da comunidade monástica.

\subsection{Descrição codicológica do manuscrito}

Este manuscrito, em pergaminho de boa qualidade, de tacto macio e de espessura média (Guerra 2003: 88 e 97), encontra-se em mau estado de conservação: a margem inferior dos fólios está bastante danificada ${ }^{14}$, decerto pelo uso intenso, o que favoreceu o desgaste material dos mesmos. O manuscrito mede 265 x $185 \mathrm{~mm}$ e totaliza 154 fólios, divididos em 19 cadernos (quaternos), com algumas exceções, assinaladas na Tabela 1, que nos merecem alguns comentários. O $1^{\circ}$ caderno, com seis fólios, é uma adição posterior. Os últimos fólios (fls. 150-154) foram adicionados ao núcleo inicial do manuscrito, em cronologias diferentes e que importa contextualizar devidamente, no âmbito da análise litúrgica. O $3^{\circ}$ caderno, só com 7 fólios, não teve perda de texto ${ }^{15}$, mas resultou decerto de um aproveitamento de pergaminho. No que diz respeito aos reclames, só são visíveis no $16^{\circ}, 17^{\circ}$ e $18^{\circ}$ cadernos, cuja numeração, em algarismos romanos, coincide com o número de cadernos do núcleo do manuscrito, ou seja, XV, XVI e XVII, respetivamente. A foliação é moderna, feita a lápis na margem superior e o manuscrito exibe o carimbo da livraria de Alcobaça (fólios 1 e 2).

O texto apresenta-se numa só coluna, com 15 linhas, à exceção do Calendário e das adições, e a primeira linha de texto de cada fólio situa-se acima da caixa de texto, uma característica comum a manuscritos anteriores ao séc. XIII (Muzerelle 2013: 115). No que diz respeito ao tipo de letra, parece-nos um tipo de letra de transição da carolina para a gótica, mais concretamente protogótica porque já apresenta algumas das características da escrita gótica (traços de arranque e de fuga nas hastes das letras, que as adensam nas pontas, e a alternância entre traços finos e grossos), mais precisamente littera protogothica formata (Amos II 1989: 33). A uni-

\footnotetext{
14 Agradecemos de forma penhorada ao Serviço de Reservados da Biblioteca Nacional de Portugal, nomea-

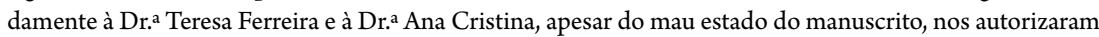
a sua consulta e a realização de fotografias para o podermos estudar.

15 Há continuidade entre a feria III do fólio $28 \mathrm{v}$ e o inicio do fólio 29 , com a feria IIII.
} 
dade de regramento (UR) do núcleo do manuscrito é bastante regular, cujo regramento, feito a ponta seca, está de acordo com os dados levantados para alguma da documentação desta época, em Alcobaça (Guerra 2003: 135) e por isso integráveis num bom planeamento de trabalho, bastante cuidado (Nascimento 2016: 38). O picotamento dos fólios só raramente é visível, decerto por terem sido aparados, embora também se verifique o desgaste dos mesmos na margem de goteira, decorrente do manuseamento significativo. $\mathrm{O}$ manuscrito está iluminado com grandes iniciais folheadas, de dimensão variável, que refletem uma organização hierarquizada da ornamentação em relação às festas que assinalam; iniciais mais pequenas foram usadas para pontuar as festas de menor importância litúrgica ( 3 a 4 UR) e o início das coletas (2 UR), cujas características desenvolveremos mais adiante.

No que concerne à encadernação do manuscrito, mede 288 x $185 \times 65 \mathrm{~mm}$ e apresenta pastas de papelão cobertas por pele castanha. Devido ao desmembramento da encadernação, as pastas estão soltas, bem como a lombada, exibindo cinco nervos e as respetivas tranchefilas da cabeça e pé. Há destacamento da pele em alguns locais das pastas. As folhas de guarda são em papel, tal como a primeira folha do manuscrito que, para além da cota antiga e do nome do manuscrito em latim, exibe o carimbo da livraria de Alcobaça.

De referir, e porque nos parece importante para contextualizar o tempo de uso deste manuscrito, que, nos últimos cadernos, nomeadamente a partir do fl. 146, a margem inferior dos fólios se encontra num significativo estado de degradação, com perda de pergaminho: o manuscrito parece ter sofrido algumas intervenções de "restauro" que, pelas suas características, devem ter sido realizadas pelos próprios monges e que consistiram em agregar, à margem de pé dos fólios, através de colagem, fragmentos de outros manuscritos, de diferentes cronologias ${ }^{16}$.

\subsection{Conteúdo litúrgico do manuscrito e sua datação}

O conteúdo litúrgico de um manuscrito constitui-se como um tema de grande interesse, e é geralmente a análise do Calendário, do Próprio dos Santos e das adições, em articulação com os Statuta Capitulorum, que nos permite chegar a uma datação aproximada ${ }^{17}$, exercício que nem sempre é possível. É nossa intenção neste artigo confirmar a data de produção deste manuscrito no séc. XII, como é referido no Inventário ${ }^{18} \mathrm{e}$ a sua associação ao scriptorium de Alcobaça. Em relação ao seu conteúdo, as suas seções foram estruturadas na Tabela 1.

\footnotetext{
16 Estas intervenções são comuns nos manuscritos de Alcobaça. No Alc. 63, um Ordinário do Oficio Divino de 1483 , no fl. 148v inclui uma receita "para solfar qualquer livro velho que for roto antes que se encaderne" (Nascimento e Diogo 1984: 89).

17 Ver Leroquais 1934: XCVII e seguintes; Canivez 1933/41; Waddell 2002 e Legendre 2008: 186-187.

18 Melo 1930/2: 135 e 136; Nascimento 1978: 11.
} 
Tabela 1. Conteúdo do manuscrito Alc. 166

\begin{tabular}{|c|c|c|}
\hline Cadernos & Fólios & Conteúdo \\
\hline $1^{\circ}$ (6 fólios $)$ & Fl. 1 ao fl. $6 \mathrm{v}$ & (Adição) Calendário \\
\hline 20 & Fl. 7 ao fl. $14 \mathrm{v}$ & \multirow{7}{*}{$\begin{array}{l}\text { Colecta de Sta. Ursula (fl. } 7 \text { ). } \\
\text { Próprio do Tempo (fl. } 7 \mathrm{v} \text { em diante): do } 1^{\circ} \text { domingo do } \\
\text { Advento ao } 25^{\circ} \text { domingo (fl. } 64 \mathrm{v} \text { ). }\end{array}$} \\
\hline $3^{\circ}$ (7 fólios $)$ & Fl. 15 ao fl. $22 \mathrm{v}$ & \\
\hline $4^{\circ}$ & Fl. 23 ao fl. $29 \mathrm{v}$ & \\
\hline $5^{\circ}$ & Fl. 30 ao fl. $37 \mathrm{v}$ & \\
\hline $6^{\circ}$ & Fl. 38 ao fl. $45 \mathrm{v}$ & \\
\hline $7^{\circ}$ & Fl. 46 ao fl. $53 \mathrm{v}$ & \\
\hline $8^{\circ}$ & Fl. 54 ao fl. $61 \mathrm{v}$ & \\
\hline $9^{\circ}$ & Fl. 62 ao fl. $69 \mathrm{v}$ & \multirow{5}{*}{ Próprio dos Santos (início fl. 65). } \\
\hline $10^{\circ}$ & Fl. 70 ao fl. $77 \mathrm{v}$ & \\
\hline $11^{\circ}$ & Fl. 78 ao fl. $85 \mathrm{v}$ & \\
\hline $12^{\circ}$ & Fl. 86 ao fl. $93 \mathrm{v}$ & \\
\hline $13^{\circ}$ & Fl. 94 ao fl. $101 \mathrm{v}$ & \\
\hline $14^{\circ}$ & Fl. 102 ao fl. $109 \mathrm{v}$ & \multirow[b]{2}{*}{$\begin{array}{l}\text { Continuação do Próprio dos Santos (termina no fl. 104). } \\
\text { Comum dos Santos (início fl. } 104 \text { até ao fl. 115). } \\
\text { Coletas para a Dedicação da Igreja; Nova dedicação da } \\
\text { igreja e aniversário (termina fl. 116v) } \\
\text { Orações (fl. 116v ao fl. 118): } \\
\text { Oratio super fratres egredientes de coquina } \\
\text { Oratio super egredientes } \\
\text { Oratio super fratres redeuntes de uia }\end{array}$} \\
\hline $15^{\circ}$ & Fl. 110 ao fl. $117 \mathrm{v}$ & \\
\hline $16^{\circ}$ & Fl. 118 ao fl. $125 \mathrm{v}$ & Ordo ad inungendum infirmum (fl. 118 ao fl. 125v). \\
\hline $17^{\circ}$ & Fl. 126 ao fl. $133 \mathrm{v}$ & \multirow{2}{*}{ Ordo sepeliendi defunctum (início no fl. $125 \mathrm{v}$ ao fl. $142 \mathrm{v}$ ). } \\
\hline $18^{\circ}$ & Fl. 134 ao fl. $141 \mathrm{v}$ & \\
\hline $19^{\circ}$ & Fl. 142 ao fl $149 \mathrm{v}$ & $\begin{array}{l}\text { Continuação do Ordo sepeliendi defunctum (termina no fl. } \\
142 \mathrm{v} \text { ). } \\
\text { Coletas para as comemorações dos aniversários pelos } \\
\text { defuntos (fl. } 142 \text { ao fl. 147). } \\
\text { Adições (fl. } 147 \mathrm{v} \text { ao fl. 149). }\end{array}$ \\
\hline 5 fólios & Fl. 150 ao fl. 154 & Continuação das adições (até ao fl. 153v; fl. 154 vazio). \\
\hline
\end{tabular}

Assim, no que diz respeito ao Calendário, o Inventário refere que se trata de uma adição, um caderno de seis fólios acrescentado posteriormente ao manuscrito $^{19}$, uma informação que a nossa observação codicológica e a análise das festividades veio a confirmar. Daqui se depreende que o Calendário não estava previsto no projeto inicial deste Coletário-ritual. Desconhecemos a data em que o Calendário foi agregado ao núcleo do manuscrito mas, a avaliar pelo estado de degradação da margem inferior dos fólios, o desgaste parece ter ocorrido numa fase em que $o$

19 Melo 1930: 135; Miranda 1996: 265. 
Calendário já havia sido adicionado ao núcleo primitivo. E de certeza muito antes de o manuscrito ter recebido a encadernação atual e o carimbo da livraria.

O Calendário é um importante instrumento de organização do culto, onde estão assinaladas as festas autorizadas pelos Capítulos Gerais, de modo hierarquizado e com indicações para a sua celebração: as mais importantes são as festas com doze lições $(X I I l c)$ e, de seguida, as comemorações (cõm). Geralmente, as primeiras beneficiam de um ofício específico no Próprio dos Santos (Lebigue 2014: 41 e seguintes; Maître 2015: 17).

Tabela 2. Calendário do Alc. 166

\begin{tabular}{|c|c|c|}
\hline Data e santo & $\begin{array}{c}\text { Data da autorização pelo } \\
\text { Capítulo Geral }\end{array}$ & Calendário \\
\hline Janeiro, 3: Sta. Genoveva & 1257 (com.) & Adição \\
\hline Janeiro, 17: Sto. Antão abade & 1260 (XII lc, 1 missa) & Quase apagado \\
\hline Fevereiro, 1: Vigília Purificação da Virgem & 1294 & Não \\
\hline Fevereiro, 9: 8a Purificação da Virgem & 1294 & Não \\
\hline Março, 20: S. Cuthberto bispo e conf. & 1226 (com.) & Sim \\
\hline Abril 29: Roberto abade & 1259 (2 missas) & Quase apagado \\
\hline Maio, 6: S. João ante portam latinam & 1246 (XII lc, 1 missa) & Sim \\
\hline Junho, 13: Sto. António de Lisboa & & Adição \\
\hline Junho, 28: S. Julião de Mans & 1267 & Não \\
\hline Julho, 20: Sta. Margarida & 1260 (com.) & Sim \\
\hline Agosto, 5: S. Domingos & 1255 (XII lc, 1 missa) & Adição \\
\hline Agosto, 11: Coroa de Espinhos & 1292 & Adição \\
\hline Agosto, 25: S. Ludovico conf. & 1298 (XII lc, 2 missas) & Adição \\
\hline Agosto, 27: 8. a S. Bernardo & 1295 (XII lc, 1 missa) & Adição \\
\hline $\begin{array}{l}\text { Setembro, 7: Vigília da Festa da } \\
\text { Natividade da Virgem }\end{array}$ & 1292 & Não \\
\hline $\begin{array}{l}\text { Setembro, 15: Oitava da Natividade } \\
\text { da Virgem }\end{array}$ & 1245 & Sim \\
\hline Setembro, 17: S. Lamberto bispo & 1246 (XII lc, 1 missa) & Sim \\
\hline Outubro, 4: S. Francisco conf. & 1259 (XII lc, 1 missa) & Sim \\
\hline Outubro, 20: Dedicação de Alcobaça & (20 de outubro de) 1252 & Sim \\
\hline Outubro, 21: Onze Mil Virgens & $\begin{array}{l}1220 \text { (com.); } 1260 \text { (XII lc, } \\
1 \text { missa); } 1262 \text { (2 missas) }\end{array}$ & Adição \\
\hline Novembro, 16: Sto. Edmundo bispo & $\begin{array}{l}\text { Em } 1247 \text { a festa passou a } \\
\text { ser assinalada a } 8 \text { de junho }\end{array}$ & Sim \\
\hline Novembro, 19: Sta. Isabel & 1235 (com.) & Adição \\
\hline Dezembro, 1: Sto. Elígio bispo & 1230 (com); 1287 (XII lc) & $\begin{array}{l}\text { Sim: a com. foi raspada } \\
\text { e por cima XII lc }\end{array}$ \\
\hline
\end{tabular}

O pergaminho do Calendário encontra-se deteriorado, em particular na margem inferior dos fólios, pelo que não é muito claro afirmar com certeza se determi- 


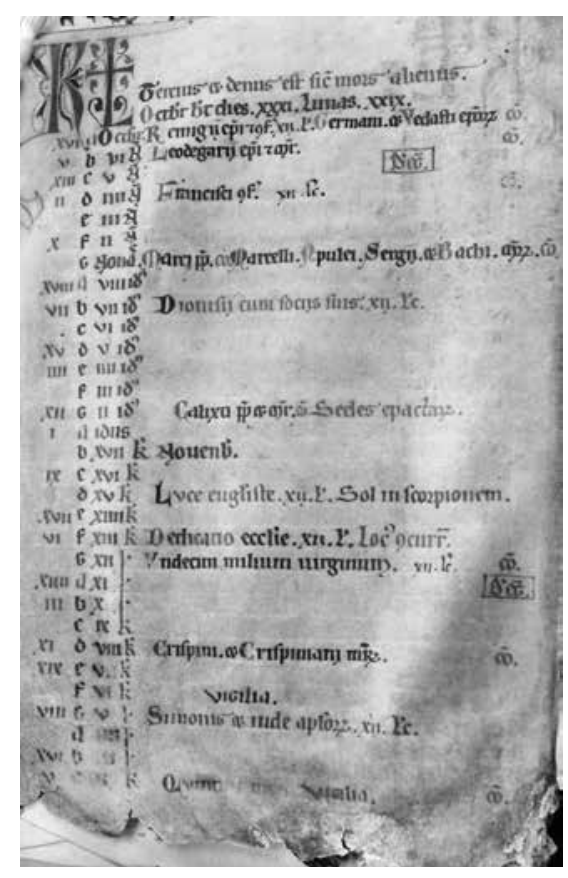

Fig. 1. Calendário, fólio do mês de Outubro (fl. 5v), BNP, Alc. 166, Coletário-ritual, Fotografia de Catarina Fernandes Barreira nada festa, correspondente aos últimos dias de cada mês, foi ou não adicionada. A partir da sua análise, este Calendário tem assinalada, a 20 de outubro, a festa da Dedicatio ecclesie (fl. 5v, Fig. 1), implicando a sua elaboração em data posterior a 1252. Uma data que podemos dilatar mais um pouco, porque tem indicadas as festas de S. Francisco (1259) e a Sta. Margarida $(1260)^{20}$. Desconhecemos porque é que determinadas festas, como a de Sta. Isabel (1235), S. Domingos (1255) e Sta. Genoveva (1257) aparecem sob a forma de adições. Ou porque é que a festa das Onze Mil Virgens aparece assinalada primeiro como uma comemoração (1220) e, adicionada por mão distinta, as doze lições (1260, mesmo ano que Sta. Margarida). Terá o calendário sido copiado por um modelo anterior, elaborado antes de 1247 (data em que a festa de S. Edmundo passou a ser assinalada no dia 8 de junho) ou mais recuado, até 1235, por causa de Sta. Isabel e que, por motivos que ignoramos, este Calendário não foi atualizado em relação a algumas festividades? Assim, de acordo com os dados disponíveis, terá sido em torno de 1260 que o Calendário foi agregado ao núcleo do manuscrito, uma vez que não há motivos para pensarmos que não tenha sido feito intencionalmente para este códice.

Segundo Nicolas Bell, uma razão que pode justificar algumas destas discrepâncias, é que, na prática:

"the application of these changes to the calendar was far less systematic than the General Chapter intended: it depended on abbots being present at the meetings, and their diligence in passing the necessary emendations on for inclusion in the books." (Bell 2013: 264).

Neste Calendário foram ainda assinalados, em data posterior à data da cópia do Calendário, os aniversários do rei Afonso II, a 25 de março (fl. 2), o da rainha

20 "Item statuit et ordinat Capitulum generale ut commemoratio beatae Margarrethae fiat tertio decimo kalendas augusti per Ordinem universum. Collecta : omnipotens sempiterne Deus, qui infirma." (Canivez II 1934: 464). 
sua mulher. D. Urraca, no dia 4 de novembro (fl. 6) e por fim, o aniversário de D. Afonso, primeiro rei de Portugal, a 5 de dezembro (fl. 6v). Ou seja, nos dias indicados, correspondentes às datas dos óbitos dos sufragados, lembravam-se o rei fundador, cuja memória vai ser enaltecida em Alcobaça pelo menos até aos finais do séc. $\mathrm{XV}$, inícios do $\mathrm{XVI}^{21}$, bem como dos dois monarcas que estavam tumulados na galilé, à entrada da igreja, assunto que já abordámos noutro lugar (Rêpas e Barreira 2016: 220). Estes dados documentam que, em Alcobaça, a partir da 2. a metade do séc. XIII, já se começa a organizar uma "liturgia funerária em função dos benfeitores do mosteiro" (Mattoso 2001: 81).

No que concerne ao cromatismo do Calendário, as festas de doze lições foram escritas com vermelhão, vermelho-escuro e verde, em alternância; as comemorações escritas a tinta de escrita/preto. Este significado das cores em relação à hierarquia das festas nos Calendários teve início em meados do séc. XIII e não se verifica nos calendários mais antigos (Lebigue 2014: 60). Desconhecemos em que data é que começou a ser aplicada nos Calendários de Alcobaça, mas este Calendário deve ter sido um dos primeiros a exibir esta organização.

Em relação ao núcleo do Coletário-ritual, ele tem início com o Próprio do Tempo, com as coletas para o Ofício do $1^{\circ}$ domingo do Advento (fl. 7v), passando pela Festa da Santíssima Trindade (fl. 58v), autorizada em $1175^{22}$ e termina com as coletas respeitantes ao $25^{\circ}$ Domingo depois do Pentecostes (fl. 64v).

O Santoral inicia-se com a festa de Sto. Estevão ${ }^{23}$ (fl. 65, Fig. 2) celebrado a 26 de dezembro, e vai até às coletas

21 Este aniversário foi também assinalado no Calendário do Alc. 63, um Ordinário do Oficio Divino de 1483. A propósito da memória do

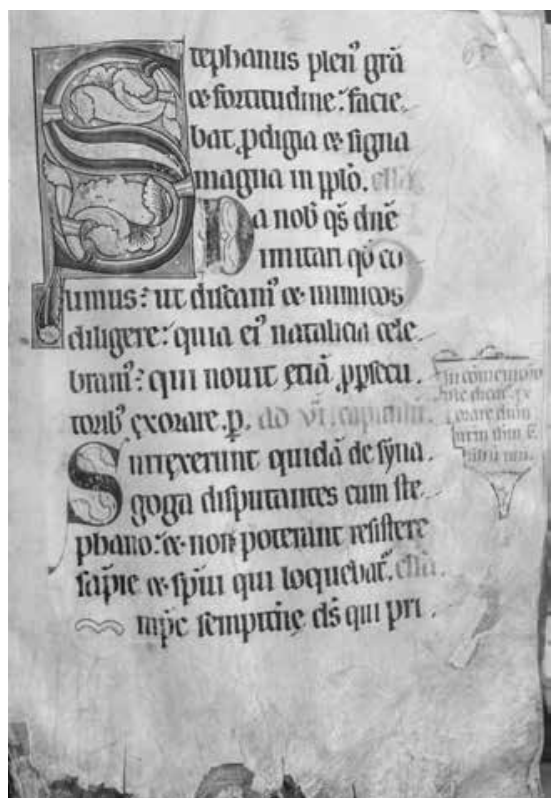

Fig. 2. Início do Santoral (fl. 65), BNP, Alc. 166, Coletário-ritual, Fotografia de Catarina Fernandes Barreira primeiro rei em Alcobaça ver Rêpas e Barreira 2016: 230; Sobre as memórias relativamente aos reis da primeira dinastia até D. Afonso IV, temos o Chronicon, uma adição inserida no final do Alc. 66, um breviário de inícios do séc. XIV. Com uma lista dos Reis que foram em Portugal, ver também o Alc. 62, um Ordinário do Ofício Divino in Barreira 2016b e Barreira 2015.

22 "Hystoria de Trinitate cantabitur et missa dicetur sicut in festo unius apostoli" (Leroquais 1934: XCVII).

23 Sobre a questão do início do Santoral com Estevão ver: Zaluska e Damongeot 2015: 108; Baury 2010: 160; Bell 2013: 260; Barreira et al. 2016: 260; Barreira 2016a. 
de Sto. André apóstolo (fl. 104), a 30 de novembro. É através das festividades que integram o Próprio dos Santos, em articulação com o Capítulo Geral, e das informações contidas nas anotações das margens, que vamos propor uma data para a elaboração do núcleo deste Coletário-ritual. As indicações nas margens dos fólios respeitantes ao Santoral são em número significativo e documentam um trabalho de constante atualização em relação às comemorações litúrgicas autorizadas pelo Capítulo Geral, sob a forma de notas e apontamentos marginais que se estendem, pelo menos, até finais do séc. XIII.

Pela análise do Santoral e do confronto com as notas nas margens, cujos dados estão compilados na Tabela 3, este manuscrito deve ser posterior a $1185^{24}$ e anterior a 1191, confirmando-se assim o funcionamento do scriptorium alcobacense neste período, o que está de acordo com o documentado, por outras vias, por António Joaquim R. Guerra (Guerra 2003: 226).

Tabela 3. Santoral do Colectário Alc. 166

\begin{tabular}{|l|l|l|}
\hline \multicolumn{1}{|c|}{ Santo } & \multicolumn{1}{|c|}{$\begin{array}{c}\text { Data da autorização do } \\
\text { Capítulo Geral }\end{array}$} & \multicolumn{1}{c|}{ Menção no Santoral } \\
\hline Sta. Maria Madalena & $1175:$ XII Lc & Sim \\
\hline S. Bernardo de Claraval & $1175:$ XII Lc & $\begin{array}{l}\text { Sim (com a indicação de que se } \\
\text { deve fazer como para S. Bento) }\end{array}$ \\
\hline S. Vicente ${ }^{1}$ & $1184(2$ missas); 1185: XII lc & Sim \\
\hline S. Tomás, bispo de Cantuária ${ }^{2}$ & $1185: 1$ missa $(1191: 2$ missas) & Sim \\
\hline S. Marcial, bispo & 1991 (comm.) & Não: refa na margem \\
\hline S. Malaquias, bispo & $1991:$ XII Lc & Não: refa na margem \\
\hline S. Julião (Mans) bispo e conf. & 1193 (comm.) & Não: refa na margem \\
\hline S. Pedro de Tarentaise, bispo e conf. ${ }^{3}$ & 1196 & Não: refa na margem \\
\hline Sto. Antão (abade) ${ }^{4}$ & 1198 (comm); $1260:$ XII Lc & Não: refa na margem \\
\hline S. Nicolau, bispo ${ }^{5}$ & $1199:$ XII Lc e 2 missas & Sim \\
\hline
\end{tabular}

${ }^{1}$ Sobre esta celebração, ver Waddel, 2002: 129

2 Sobre esta festividade ver Waddell, 2002: 125. O estatuto que se refere a esta festividade, em 1185, apenas lembra que este santo é para ser celebrado com duas missas pelos cistercienses ingleses e com uma missa por toda a ordem. Ver também Cavero Dominguez et al, 2013: 154 e seguintes, sobre as coletas deste santo.

${ }^{3}$ Waddell, 2002: 374, 379 e 402.

${ }^{4}$ Waddell, 2002: 403.

5 A partir do levantamento feito por Leroquais, vemos que a festa de S. Nicolau foi autorizada a sua celebração, em 1199, com duas missas (Leroquais, 1934: XCVIII). Destacamos, no entanto, que a festa já era celebrada antes, com doze lições e uma missa (Waddell: 2002: 424) e por isso não é de estranhar que apareça no Santoral.

24 Nos Statuta de 1186, há uma indicação sobre a celebração em honra de S. Nicomedes em Cister e nas outras abadias (Waddell 2002: 134). O Santoral deste Coletário tem assinalada a sua comemoração. 
Ao Santoral sucedem-se as coletas do Comum dos Santos, da Dedicação da Igreja, nova Dedicação e as coletas do aniversário da Dedicação (fls. 115 a 116v); em seguida três orações: Oratio super fratres egredientes de coquina ${ }^{25}$, Oratio super egredientes e Oratio super fratres redeuntes de uia ${ }^{26}$. Sobre estas orações, a primeira recitada sobre os frades ao sair da cozinha, e a última sobre os frades regressados da rua, Michel Andrieu menciona que estas fórmulas, entre outras, são comuns nos Pontificais e provêm do Sacramentário Gelasiano do séc. VIII, escrito por um monge (Andrieu 1931: 531; Vogel 1958: 117). No universo dos manuscritos cistercienses, registámos a presença destas orações no manuscrito Dijon 114, um códice copiado entre 1182 e 1188 no Mosteiro de Cister (Berman 2010: 48 e 244) para servir de exemplar, um modelo ${ }^{27}$ a partir do qual seriam copiados os manuscritos necessários à fundação de uma nova abadia, no intuito de assegurar uma prática litúrgica uniforme (Bell 2013: 263; Falmagne 2012: 17). As referidas orações, entre outras orações e bênçãos, aparecem sequencialmente, tal como neste manuscrito, na parte respeitante ao Coletário (fl. 148v): a seguir ao Comum dos Santos e da Dedicação da igreja e antes dos dois ordines que vamos tratar em seguida.

O Alc. 166 prossegue ${ }^{28}$ com dois rituais, o Ordo ad inungendum infirmum, ou sacramento da unção dos enfermos e o Ordo ad inhumandum fratrem mortuum, ou ritual dos defuntos. Estes ordines mereceram ambos um estudo de José Mattoso a propósito da sua origem e das diferenças face aos rituais de Cluny (Mattoso 2001: 63 a 82). Também nós tivemos oportunidade de os estudar muito recentemente noutro lado, a propósito de um outro manuscrito de Alcobaça, um Ritual (Rêpas e Barreira 2016: 216; Barreira et al. 2016: 258). Pensamos que este Coletário-ritual é o testemunho mais antigo que conhecemos dos dois ordines em Alcobaça, documentados posteriormente num conjunto de outros manuscritos (Bragança 2008: 426; Rêpas e Barreira, 2016: 216). Em relação ao primeiro Ordo, a unção dos enfermos, este aparece sempre acompanhado por uma Ladainha dos Santos (Fig. 3) que assinala o momento em que a morte se aproxima e todos os monges se reúnem em torno do irmão agonizante, após a recitação do Credo, invocando a intercessão de toda a Corte celeste (Mattoso 2001: 66).

25 Ver Regra de S. Bento (Costa 2007: 104).

26 Ver Regra de S. Bento (Costa 2007: 148).

27 "In hoc volumine continetur libri ad divinum officium pertinentes quos utique non dicet in ordine nostro diversos habere. Sunt autem hic in unum corpus ea maxime ratione redacti ut presens liber sit exemplar invariable ad conservandam uniformitatem et corrigendam in aliis diversitatem." (Berman 2010: 244).

28 Na mudança de caderno, entre o fl. $117 \mathrm{v}$ e o fl. 118 (ver Tabela 1), o n. ${ }^{\circ}$ de linhas por fólio passa a oscilar entre 14 e 15 linhas e a distância entre as linhas de regramento aumenta ligeiramente (passa de $13 \mathrm{~mm}$ para $14 \mathrm{~mm})$. 


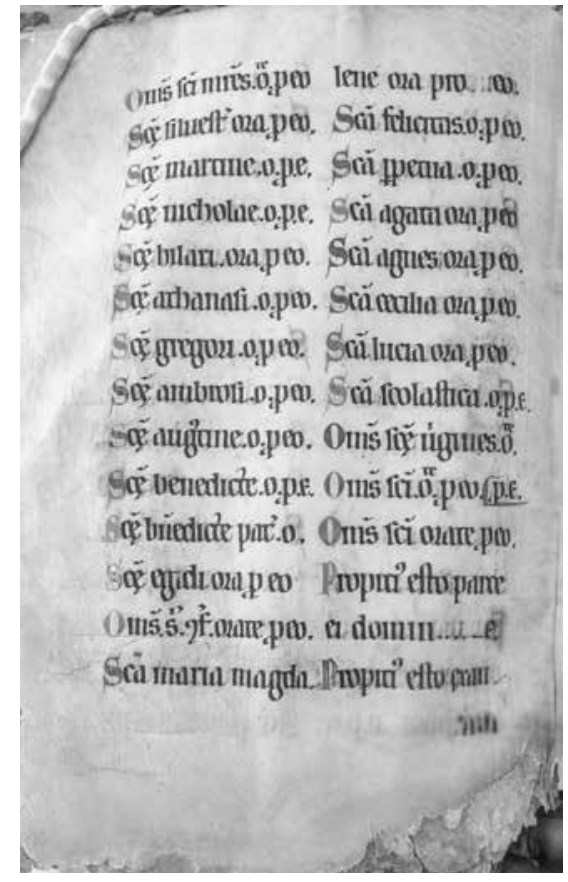

Fig. 3. Ladainha dos Santos (fl. 125v), BNP, Alc. 166, Coletário-ritual, Fotografia de Catarina Fernandes Barreira
A Ladainha é outro elemento importante para confirmar a datação deste manuscrito no intervalo 1185 1191, devido aos santos aí invocados, que careciam também de autorização dos Capítulos Gerais. Segundo Manuel Pedro Ferreira:

"the introduction of a new saint in the Litany apparently required a commemoration with a feast of twelve lessons; but this was not always enough (...) For example, St. Bernard himself was commemorated with solemn Matins and two masses a quarter-century before he was introduced into the Litany." (Ferreira 2013: 297).

A Ladainha dos Santos do sacramento da extrema-unção do Coletário - ritual Alc. 166 corresponde totalmente à Ladainha do mesmo ordo do manuscrito Dijon 114, fl. 149v. Destacamos, em ambas, a ausência de $\mathrm{S}$. Bernardo, cuja invocação só foi autorizada em 1200. A seguir à Ladainha, temos o Ordo ad inhumandum, ou Ordo sepeliendi defunctumum ritual mais longo, que vai desde a preparação do corpo do monge falecido, à sua condução até à igreja, para a celebração dos ofícios de corpo presente (ofício dos defuntos e missa), concluindo com a procissão que acompanha o cadáver até ao cemitério e as orações aí proferidas (Mattoso 2001: 67 e 68$)$.

Depois do ritual das exéquias, o Alc. 166 prossegue com um conjunto de coletas para a celebração dos aniversários pelos defuntos (fls. 142-145). Estas comemorações, em honra dos bispos e abades da ordem, dos monges e familiares da ordem, de caracter coletivo, também se encontram no já mencionado manuscrito Dijon 114 (fl. 151) e desenrolam-se pela mesma ordem. Sobre estes sufrágios, Mattoso menciona, no âmbito do culto dos mortos em Cister, que "os monges brancos restringiram drasticamente os sufrágios pelos estranhos, mas aumentaram-nos pelos membros da sua ordem" (Mattoso 2001: 79 e 80). Os sufrágios são os seguintes (por questões de espaço, não indicamos as coletas): Pro episcopo defuncto; In aniversario episcoporum et abbatum; Per presenti defuncto; Pro tricenario et in commune parentum nostrum; Pro femina defuncta; Fratribus nostre congregationis et parentibus nostris e por fim, Pro tri- 
cenario cisterciense (fl. 144v) ${ }^{29}$. Em Alcobaça, estes sufrágios reaparecem nos seguintes manuscritos, por ordem cronológica: Alc. 67, um Coletário para a tércia, de 1442; Alc. 278, um Livro de Usos de 1444; numa adição do séc. XV do Breviário Alc. 54; no Ritual de Salzedas de finais do séc. XV, inícios da centúria seguinte e no Alc. 105, um Caeremoniale monasticum de 1716 (Rêpas e Barreira 2016: 218).

Seguem-se algumas bênçãos (fls. 145 e 145v) e o Pater noster. Estas bênçãos também estão no manuscrito Dijon 114, fl. 151, na parte respeitante ao Coletário. É interessante perceber os paralelismos entre os dois manuscritos, nomeadamente ao nível da sequência pela qual se apresentam: a seguir ao Comum dos Santos, ambos têm a Dedicação da igreja, as orações, os rituais da unção dos enfermos e das exéquias, as coletas pelos aniversários dos defuntos e as bênçãos. O manuscrito Dijon 114 prossegue com o Calendário, o alcobacense continua com um conjunto de coletas para o Santoral, que foram sendo adicionadas num intervalo cronológico que não é desprovido de interesse.

As adições de coletas ao núcleo primitivo deste Coletário - ritual (com início no fl. $147 \mathrm{v}$ ) e a sua ordem também ajudam a confirmar as datações propostas e o tempo de uso do manuscrito: à coleta de S. Bernardo (com missa própria em 1202) sucede a de Sta. Catarina (1207); no fl. 148, a coleta Undecim milium virginum $\left(1220^{30}\right)$ e de Sto. Edmundo, arcebispo (1247); no fl. 148v os capitula e as coletas para as horas de vesperas, laudes, prima, sexta e nona do ofício Undecim milium virginum $\left(1260^{31}\right)$; no fl. 149, os capitula e as coletas para as horas de vesperas, laudes, prima, sexta e nona do ofício In solemnitatis sacramenti altaris (1318); S. Malaquias (oficio próprio para Claraval em 1274; 1295 para toda a ordem $\left.{ }^{32}\right)$; no fl. 151, In conceptione beate Marie $(1356)^{33}$ e Beate Anne, mãe da Virgem (1366 para a sua comemoração; doze lições/ uma missa, à consideração do mosteiro, em 1375; com doze lições em 1454) ${ }^{34}$. No

29 Sobre a celebração destes sufrágios na abadia de Alcobaça, ver Rêpas e Barreira 2016: 218 e seguintes.

30 Segundo Manuel Pedro Ferreira, 1220 para as casas femininas da Ordem (Ferreira 2013: 300). "Petitio Domini Coloniensis super Commemoratione undecim martyrum vigilia facienda annuatim in festum earum admittitur, duodecimo kalendas novembris ad vesperas antiphona $O$ quam pulchra es amica mea; in laudibus antiphona Prudentes Virgines, versus Adducentur regi virgines; collecta : Exaudi nos Deus personaliter." (Canivez I 1933: 518).

31 "Item petitio illustrissimi regis Francorum de faciendo officio undecim millium virginum cum duodecim lectionibus et una missa in universis abbatiis, exauditur, et iungitur de Campo et de Valle Sancti Lamberti abbatibus ut ad inveniendum ipsarum officum quam citius fieri poterit diligentius elaborent; et ipsum officium deferant ad proximam sequens Capitulum generale." (Canivez II 1934: 464).

32 "Item, quoniam sanctorum splendor mirabilis indeficienti lumine ubique radiat et coruscat, ad honorem beatissimi patris nostri Bernardi, qui totum Ordinem nostrum decorat, illuminat et venustat, generale Capitulum ordinat et diffinit quod in die octavo festivitatis eius duodecim lectiones et una missa per universum Ordinem habeantur, et quod historia propria B. Malachiae episcopi per totum Ordinem decantetur." (Canivez III 1935: 279)

33 Maître 2015: 19, 21 e 22.

34 Leroquais 1934: XCIX; Maître 2015: 19, 21 e 22. 


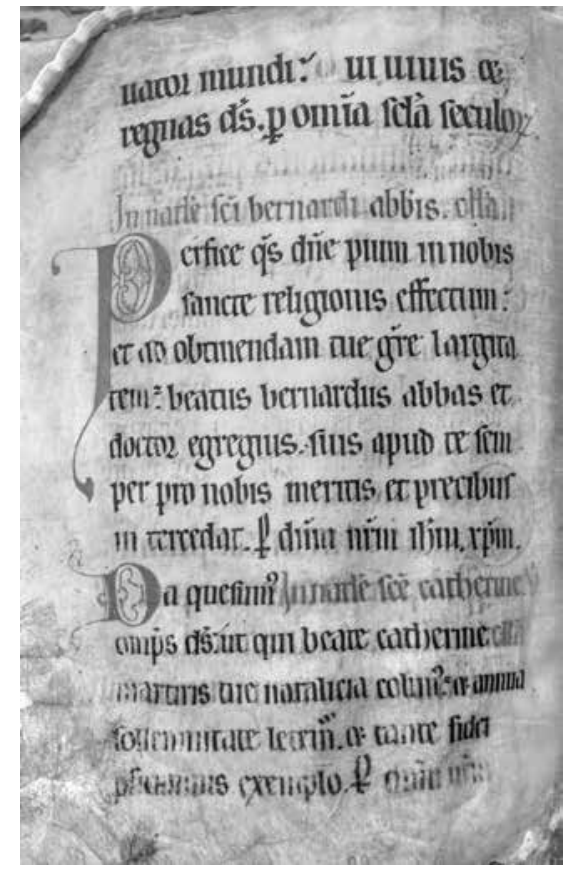

Fig. 4. Coletas de S. Bernardo e Sta. Catarina (fl. 147v) BNP, Alc. 166, Coletário-ritual, Fotografia de Catarina Fernandes Barreira que diz respeito ao tipo de letra, o ofício anterior, In conceptione beate Marie apresenta muitas semelhanças com o tipo de letra dos manuscritos alcobacenses da 2. ${ }^{\text {a }}$ metade do séc. XV, bem como as suas iniciais de cor, e o ofício respeitante a Sta. Ana parece ser já em letra do séc. XVI. Estas adições ao núcleo do manuscrito, que vão desde 1202 aos finais do séc. $X V$, inícios do séc. $X V I$, não se limitam a assinalar as novas festividades do Santoral cisterciense, mas refletem determinadas orientações litúrgicas e documentam um tempo de uso do manuscrito que se estende, pelo menos, até os inícios do séc. XVI. E, associadas à adição do Calendário, refletem uma atitude ativa e identitária face aos manuscritos litúrgicos e ao seu uso.

$\mathrm{O}$ manuscrito prossegue, no fl. 152 , com os capitula e as coletas para o ofício Exaltatione sancte corone Domini (autorizado em 1240) ${ }^{35}$ e novamente

o ofício In solemnitatis sacramenti altaris, terminando as adições com a coleta de S. Brás e uma coleta Pro infirmis, no fl. 153v. Como se percebe, a ordem cronológica anterior foi aqui contrariada. No estado atual dos nossos trabalhos, é difícil encontrar uma justificação para a repetição do ofício In solemnitatis sacramenti altaris $^{36}$, redigido sequencialmente em relação ao Exaltatione sancte corone Domini. A partir do tipo de letra e das características da decoração iluminada destes fólios, a primeira típica de meados do séc. XIV e a do segundo ofício de inícios do séc. XV, perguntamos se terão sido os fólios 152 e 153 inseridos no manuscrito, na ordem que hoje conhecemos, numa outra cronologia, contemporânea talvez da sua reencadernação? Também não sabemos se estes dois fólios foram feitos para este manuscrito.

Em síntese, ao núcleo deste Coletário-ritual, redigido entre 1185 e 1191, foi adicionado, no início do códice, um caderno com um Calendário, datado de cerca de 1260 e, no fim do manuscrito, nos últimos fólios, um conjunto de

35 Maître 2015: 19.

36 Sobre esta festividade, ver Walters, Barbara, Corrigan, Vincent and Ricketts, Peter (2006). The Feast of Corpus Christi. Pennsylvania: The Pennsylvania University Press 
coletas que testemunham a sua atualização e o seu uso de 1202 até pelo menos aos inícios do séc. XVI.

Para Isaías da Rosa Pereira, esta conexão, do Coletário, com o Ritual, é frequente, nomeadamente para manuscritos anteriores ao séc. XII (Pereira 1996: 157). A junção entre ambos ainda nos merece mais alguns comentários, porque também se verifica num outro manuscrito cisterciense, outrora pertencente ao Mosteiro de Arouca e que foi estudado por Aires A. Nascimento (Nascimento 2004: 1047 e 1048), Joaquim Oliveira Bragança (Bragança 2008: 425 e seguintes) e, em particular, por Ana Suárez González (Suárez González 2012: 87 - 114 e Suárez González 2016: 111 e 112) $)^{37}$. O manuscrito de Arouca também contém as duas orações relativas à entrada e saída de monges do Coletário-ritual de Alcobaça, bem como o ritual da unção dos enfermos. Do scriptorium de Alcobaça saiu, em 1442, um outro coletário, o Alc. 67, que também tem os ordines (unção dos enfermos e defuntos). No entanto, não podemos dizer que tenha tido muito êxito em Alcobaça, porque o que temos vindo a constatar é que os ordines mencionados (unção dos enfermos e exéquias) foram preferencialmente copiados nos breviários a partir do séc. XIII até ao séc. XV.

Por fim, ainda em relação a este Coletário-ritual, interessa-nos sublinhar a sua proximidade, do ponto de vista litúrgico, com o manuscrito Dijon 114, o que constitui um contributo significativo em torno da questão da unanimidade e uniformidade litúrgica em contexto cisterciense, um assunto que já abordámos noutro lado, ainda que para uma cronologia mais tardia (Barreira 2016a: 33 - 54).

\section{O Saltério-hinário Alc. $11^{38}$}

Com origem no mesmo contexto que o Coletário-ritual é o Saltério-hinário non feriatum Alc. 11, um manuscrito que, segundo o Índice de Aires A. Nascimento, data do séc. XII (Nascimento 1978: 523). O Saltério aparece mencionado nos Statuta como um manuscrito indispensável à fundação de novas abadias. Este tipo de manuscrito podia ser utilizado com duas funções distintas, mas próximas: a litúrgica ${ }^{39}$ e uma outra, que se relacionava com o seu uso em contexto de aprendizagem, junto dos noviços. Os monges deveriam saber de cor os 150 salmos, não só porque essa aprendizagem, que começava cedo, era funda-

37 Segundo Ana Suárez González é constituído por duas partes distintas, sendo que a parte constituída pelo Coletário e pelos diferentes rituais, deve ter sido copiada entre 1240 e 1250 (Suárez González 2012: 97 e Suárez González 2016: 111).

38 Miranda 1996: 254, 407 e 431.

39 Jean Baptiste Lebigue, sobre os Saltérios, afirma que "les psautiers sont ceux dont on peut affirmer avec le plus de certitude qu'ils n’ont jamais été utilisés lors des cérémonies liturgiques.” (Lebigue 2007: 54). 
mental para o ensino da leitura e da escrita, mas também porque os recitavam no decurso dos sete dias da semana, ao longo da sua vida monástica ${ }^{40}$.

\subsection{Descrição codicológica do manuscrito}

Este Saltério-hinário, em pergaminho macio de espessura média, revela sinais de desgaste decorrentes de uso intenso: o pergaminho está escurecido, com parte do texto esvanecido e, no canto inferior direito dos fólios, exibe marcas de utilização frequente. No entanto, o seu estado de conservação geral constitui um indício de que a encadernação exerceu, com sucesso, a sua função protetora.

O manuscrito mede $235 \times 145 \mathrm{~mm}$, e tem um total de 247 fólios, distribuídos por 31 cadernos (quaternos). Os primeiros 13 cadernos, até ao fl. $105 \mathrm{v}$, foram numerados na margem inferior, no verso dos fólios; a partir do $14^{\circ}$ caderno uns têm reclame, outros não. $\mathrm{O} 27^{\circ}$ caderno só tem 7 fólios, bem como o último caderno. O fl. 113 exibe um tipo de letra diferente e foi adicionado para substituir um fólio anterior, o último do $14^{\circ}$ caderno: talvez o fólio se tenha deteriorado a ponto de ser necessário a sua substituição por outro.

O texto distribui-se numa coluna, com 16 linhas, à exceção das adições, nos últimos fólios, com um número de linhas irregular. Também neste caso, a primeira linha de texto situa-se acima da caixa de texto, uma característica comum aos manuscritos anteriores ao séc. XIII (Muzerelle 2013: 115). Em relação ao tipo de letra, parece-nos um tipo de letra de transição ou littera protogothica formata (Amos I 1988: 21), tal como o tipo de letra do Coletário-ritual, porque já apresenta algumas das características da escrita gótica, mas não todas. A UR do núcleo do manuscrito é bastante regular, cujo regramento, quase invisível, parece ter sido feito a plumbagina (Guerra 2003: 135), sem marcas visíveis de picotamento e, tal como verificamos para o Coletário-ritual, estes dados atestam o funcionamento de um scriptorium com um cuidado planeamento de trabalho (Nascimento 2016: 38). O manuscrito tem foliação moderna, a lápis, com duas repetições (optámos por usar a foliação que o mesmo exibe, para não gerar confusões) e exibe o carimbo da livraria de Alcobaça (fls. 2 e 4).

A encadernação do manuscrito, em pastas de madeira forradas a pele castanha, revela muitos sinais de desgaste, com três nervos espalmados e visíveis na parte interior - o fólio de guarda, um fragmento de pergaminho com texto, está repuxado na zona dos nervos. O sistema de articulação entre os nervos e a tábua é mencionada por Aires A. Nascimento como uma variante de semi-sigmático C, de carácter tardio (Nascimento e Diogo 1984: 56 e 86).

O desgaste dos fólios, à semelhança do que observámos no manuscrito anterior, levou a que, na nossa opinião e a partir das características rudimentares

40 Conforme a Regra de S. Bento (Costa 2007: 85 e seguintes). 
que apresentam, um monge diligente realizasse algumas "intervenções", como, por exemplo, a que se observa no fl. 123: perdeu-se parte do fólio (e do texto) e foi adicionado um "remendo" com o texto em falta. Observámos também, no interior dos cadernos, a presença de fio de costura relativamente recente. $\mathrm{Na}$ parte correspondente ao Saltério, há alguns desenhos integrados no texto (fins de linha, interior das iniciais) que, dadas as suas características, são decerto de datação posterior.

\subsection{Conteúdo litúrgico do manuscrito}

Como fólio de guarda o códice tem um fragmento de um manuscrito litúrgico - ao que tudo indica, oriundo de um missal. O Saltério tem início no fl. $2 \mathrm{v}$, com a maior inicial ornada do manuscrito, um B de Beatus uir, com que se inicia o Salmo 1. Os Salmos destacados com iniciais folheadas foram os 20, 26, 38, 51, $52,73,79,80,97^{41}$, terminando o último salmo no fl. $188 \mathrm{v}$.

De seguida, o conjunto de cânticos destinados a serem cantados na hora de laudes: Cântico de Isaías (Is. 12); Ezequias (Is. 38, 18-20); Ana (1 Samuel 2, 1-10); $1^{\circ}$ de Moisés (Ex. 15, 1-19); Oração de Habacuc (Habuc 3, 2-19) e o $2^{\circ}$ de Moisés (Deuteronómio 32, 1-43). Seguem-se o hino Te Deum, o cântico Trium puerorum e os três cânticos do Novo Testamento: o Cântico de Zacarias (Lucas 1.68-79), o Magnificat (Lucas 1, 46-55) e o Cântico de Simeão (Lucas 2, 29-32). Estes últimos destinavam-se a ser recitados, cada dia, em Laudes, Vésperas e Completas, respetivamente. Esta secção do manuscrito termina com o Credo de Atanásio ou Symbolum Athanasianum e com o Gloria in excelsis, no fl.207v.

No fl. 208 tem início um conjunto de hinos para os Singulis diebus, destinados às diferentes horas do Oficio Divino. Em seguida, hinos organizados segundo o Temporal: para o Advento, Natividade, Epifania, Oitavas da Epifania, Quadragésima, Domingo de Ramos, etc. até Pentecostes, fl. 224v. A partir do fl. 225, os hinos do Santoral: Sto. Estevão, S. João Evangelista, Sta. Inês, In omnibus solemnpnitatibus Beate Marie, Sta. Ágata, Sta. Cruz, S. João Baptista, Apóstolos S. Pedro e S. Paulo, Maria Madalena, S. Lourenço e, no fl. 238v, está indicado De Sancto Bernardo ad vésperas com uma inicial, I e nada mais (tal como observamos num outro manuscrito, o Alc. 140). Não é claro o facto de S. Bernardo ter Ofício Próprio desde 1175, e o seu hino só aparecer mencionado, sem o respetivo texto: não dispunham os monges, à época, do seu hino? Na linha seguinte, Ad completas et ad III de octavas beate Marie, logo seguido da rubrica S. Miguel arcanjo ${ }^{42}$. No fl. 233, o hino para o

41 De modo geral e a partir do XIII, os oito salmos que "dividem" o conjunto dos 150 são os seguintes: 26, $38,52,68,80,97$ e por fim o salmo 109 (Sousa 2015: 28), o que resulta no assinalar, por meio de iniciais distintas, determinados salmos, numa seleção ligeiramente distinta da que se observa neste manuscrito.

42 Nos Statuta, em 1200: "Commemoratio beati Bernardi fiat in horis beatae Mariae in laudibus et ad vesperas. Ad vesperas : Benedictio Domini... ; ad benedictus: Consurgens diluculo... Collecta : Adesto supplicatio- 
dia de Todos-os-Santos, seguido dos hinos de S. Martinho e de Sto. André. No fl. 236v, começam os hinos do Comum dos Santos, que terminam no fl. 238v.

O manuscrito pelo qual estes hinos foram copiados resultou da segunda resenção, depois de 1140 e, tal como nos corpus de hinos que advieram desta resenção apresenta, no Temporal, e maioritariamente no Santoral, alguns hinos divididos, com a indicação - divisio - assinalada a vermelho (Waddell 1984: 88). Este conjunto de hinos aparece nos seguintes manuscritos, todos Saltérios, de datação posterior e, ao que tudo indica, copiados no scriptorium de Alcobaça: Alc. 140, Alc. 138 (ambos do séc. XIII, segundo Nascimento 1978: 523) e o Alc. 137, datado de 1346. Este ultimo integra já, sequencialmente e por extenso, os hinos de S. Vicente e de S. Bernardo (Bernardus doctor... ).

A seguir aos hinos do Comum dos Santos, Christe, cunctorum dominator alme, um hino usado em vésperas, no Oficio da Dedicação da Igreja (Waddell 2007: 637). No fl. 240 tem início uma Ladainha: a seguir ao primeiro mártir, Estevão, segue-se Lourenço, Vicente (João e Paulo adicionados na margem, com letra posterior), Martinho, Nicolau (com Pedro, Edmundo, Malaquias e Roberto assinalados na margem, com letra posterior), Bento (Bernardo adicionado na margem) e por fim nas Santas Virgens, Madalena, Ágata e Inês (com Catarina assinalada na margem, com letra posterior). As adições marginais parecem ser todas da mesma mão, com a mesma cor de tinta. A partir dos santos presentes na Ladainha e dos que foram assinalados à margem podemos dizer que a Ladainha deve ser anterior a 1191 (dada a ausência de Malaquias), ou copiada por um manuscrito anterior, mas de certeza que a Ladainha não é posterior a 1200, por causa da ausência de S. Bernardo (Choisselet e Vernet 1989: 378 e seguintes).

O fl. 242 requer a nossa atenção, a propósito de uma outra Ladainha, precedida da seguinte indicação: Quando infirmus morti penitus appropinquauerit, dicatur litania ista. Si post letaniam anima nondum egressa fuerit dicantur vii psalmi penitentiales (Choisselet e Vernet 1989: 268). É a alusão ao momento em que os monges se reúnem em torno do irmão moribundo para entoar a Ladainha e os sete salmos penitenciais, mas sem os ordines da unção dos enfermos e sem o ritual das exéquias. Esta simplificação terá a ver com fins pedagógicos, com o uso do manuscrito junto dos noviços? Esta última Ladainha é igual à do manuscrito anterior, o Coletário-ritual Alc. 166: sem a presença de S. Bernardo e com a dupla invocação de S. Bento. Este fólio tem na margem um conjunto de indicações, com letra posterior, escritas antes das informações relativas à Ladainha: Agnus dei, Kyrieleison, entre outras preces: Exurgat Deus, Saluum fac populum tuum, etc. que se leem mal. Na margem inferior, as coletas, Ecclesiae tua, que pertence ao formulário Pro adversitate ecclesiae e respetivos sufrágios; e por fim, a coleta Deus a quo sancta desideria, que pertence à Missa pro pace. Estas indicações marginais

nibus nostris, omnipotens Deus... Iustum deduxit Dominus ... et in litaniis nominetur." (Canivez I 1933: 250). 
estão todas presentes nas Definitiones relativas a 1195, mas que se reportam aos estatutos do ano anterior ${ }^{43}$.

No fl. 245v duas orações: Deus cui soli competit e Commendamus ti, domine. Os fólios seguintes são adições, inseridos no fim do último caderno (é visível a pestana de um deles no início do último caderno): o primeiro tem o hino de $\mathrm{S}$. Vicente, Sanctissimum Vincentium mundi e no verso deste, o hino de S. Bernardo, Bernardus doctor. Estas duas adições significam que o núcleo do manuscrito foi redigido em data anterior a 1175 , quando se atribui à comemoração de S. Bernardo "propriuum officium et due misse" (Canivez I 1933: 82). Ou, outra hipótese, o manuscrito que serviu de modelo a este Saltério-hinário era anterior a 1175 e não é despiciendo pensar que poderá ter sido um dos manuscritos que Claraval ofereceu a Alcobaça, aquando a sua fundação. Nesse caso, quando o scriptorium alcobacense copiou este manuscrito, inseriu nos hinos do Santoral a menção ao hino de $\mathrm{S}$. Bernardo, mas ainda não tinha o texto disponível para cópia.

No último fólio, o fl. 247, mais referências aos Statuta de 1195, n. ${ }^{\circ}$ 1: escritas a vermelho, as preces Exurgat Deus... Salvum fac populum ... e a coleta: Omnipotens sempiterne deus, in cuius manu sunt omnium potestates et omnia iura regnorum, respice ad christianorum benignus exercitum ut gentes que in sua feritate confidunt, potentie tue dextera comprimantur. E no verso, novamente a coleta Deus a quo. Perguntamos porquê esta insistência, neste manuscrito, nas orientações litúrgicas, deste Statuta de 1195? Segundo Waddell, aí se explicitam as coletas a usar nas orações contra a invasão sarracena (os Statuta de 1194 não o faziam) e, por isso, a coleta do ano anterior deveria ser emendada, substituindo-se respice ad romanum benignus imperium por respice ad christianorum benignus auxilium (cujo termo, neste manuscrito, ou de forma propositada, ou por erro de cópia, foi substituído pela palavra exercitum). Ou seja, esta adição ao núcleo do manuscrito é posterior a setembro de 1195 .

Assim, tendo em conta a ausência de S. Bernardo nas Ladainhas, o que faz com que o manuscrito seja anterior a 1200, e as informações do fl. 247, copiado depois do Capítulo Geral de 1195, fólio que deve ter sido adicionado ao núcleo do manuscrito, numa data não muito distante, podemos dizer que este Saltério-hinário deve ter sido produzido depois de 1175, porque se refere ao hino de S. Bernardo, mas antes de 1195.

\section{Os manuscritos e a sua decoração iluminada}

Em relação à ornamentação iluminada destes dois manuscritos, o seu significado só pode ser compreendido no contexto do códice, e em relação com o texto (Nascimento 2012: 320). Uma das funções da decoração iluminada é a de

43 "The present statute expands on the preceding one: on all Fridays there is to be a procession (after chapter) from chapter room into church, where the community kneels for the chanting of the seven penitential psalms, the litany (this refers to the "Short" Litany, that is, Kyrie... Christe... Kyrie), the Lord's prayer, a series of versicles and responses and the collect Ecclesiae tua." (Waddell 2002: 306 e 307). 


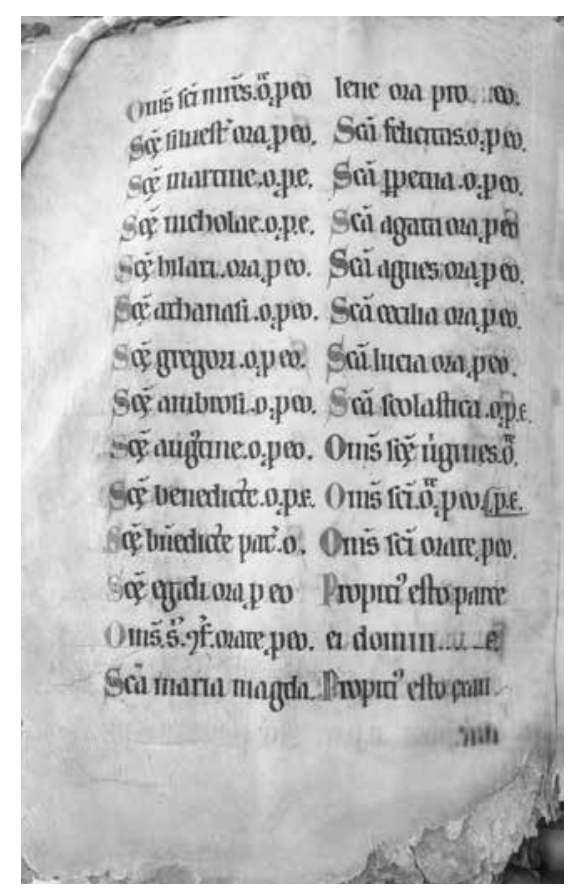

Fig. 5. Detalhe de uma inicial iluminada (fl. 90v) BNP, Alc. 166, Coletário-ritual, Fotografia de Catarina Fernandes Barreira estruturar o texto e orientar a leitura de forma organizada, através de hierarquias visuais (Nascimento 2012: 349; Coutinho 2016: 73; Miguélez Cavero et al 2016: 227 a 234).

A decoração iluminada do núcleo do Coletário-ritual foi organizada do seguinte modo: as festividades mais importantes do Temporal e do Santoral foram assinaladas com uma inicial folheada de grandes dimensões a verde, vermelho escuro, vermelhão e azul, para além do branco (para fazer matizes) e do preto (usado no contorno), por vezes emoldurada num fundo de cor, recortado. As iniciais mais pequenas, com um folheado mais discreto, utilizam duas ou três cores e foram usadas para pontuar as festas de menor importância litúrgica (3 a 4 UR) e o início das coletas (2 UR) (Miranda 1996: 266). Esta paleta de cores está de acordo com as investigações que uma equipa multidisciplinar tem vindo a confirmar para o scriptorium de Alcobaça nos sécs. XII e XIII (Miranda e Melo 2014: 13 e 14; Castro et al 2014: 42 e 43; Miguélez Cavero et al 2016: 227 a 234).

No que concerne ao Saltério-hinário, o início do Saltério exibe uma grande inicial folheada, sobre um fundo azul, já bastante desvanecida e os salmos 20, $26,38,51,52,73,79,80,97$ foram assinalados com iniciais folheadas (na iniciais verdes, por causa das características do verde garrafa, ocorreu o destacamento do pergaminho: fl. 29v, fl. 89 e fl. 99v). A pontuar o início dos cânticos e dos hinos temos iniciais de cor mais pequenas ( $2 \mathrm{UR}$ ).

Como vimos, em termos decorativos, estes dois manuscritos são distintos: os meios e o tempo empregues na decoração iluminada do Coletário-ritual diferem da iluminação, mais discreta, do Saltério-hinário. Uma razão que o justifique poderá estar no facto de, no caso do Coletário-ritual, ele ser um manuscrito de uso diário na celebração do Ofício Divino e nas orações e de utilização pontual na parte respeitante aos ordines. No caso do Saltério-hinário, apesar de conter os hinos necessários para os Ofícios, deve ter sido um manuscrito pensado também para uso dos noviços na aprendizagem dos 150 salmos e, à semelhança do manuscrito anterior, com um uso esporádico no caso da entoação das Ladainhas (Mattoso 2002: 215). 
Do ponto de vista formal, os motivos que caracterizam a decoração iluminada destes dois manuscritos - iniciais que exploram os entrelaçados e as folhagens $^{44}$ - vão caracterizar também alguns dos manuscritos seus contemporâneos, nomeadamente os volumes Alc. 420 e Alc. 422 do conjunto de códices que compõem o já referido Legendário Alcobacense, ou da Bíblia Alc. 427 - 431, em particular os códices Alc. 427 e Alc. 429. A decoração iluminada destes manuscritos influenciou a ornamentação de um conjunto de missais dos inícios do séc. XIII: Alc. 249, Alc. 251, Alc. 252, Alc. 255, Alc. 256, Alc. 257 e Alc. 259.

Tabela 4. Iniciais do Coletário-ritual e dos Missais Alc. 249, 251, 252, 257 e 259

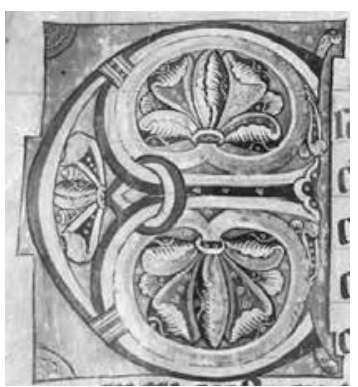

Coletário-ritual Alc. 166, fl. $7 \mathrm{v}$

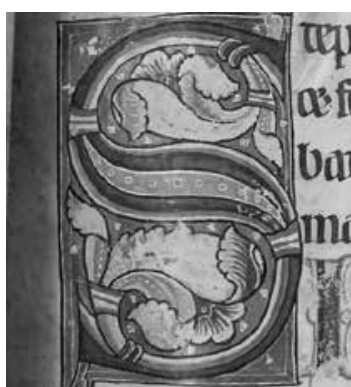

Coletário-ritual Alc. 166, fl. 65

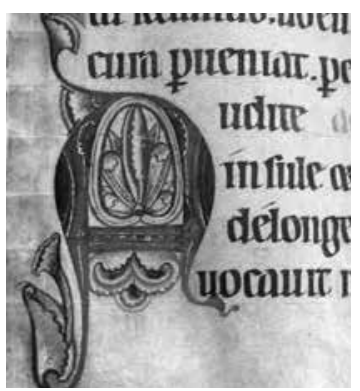

Coletário-ritual Alc. 166, fl. 80

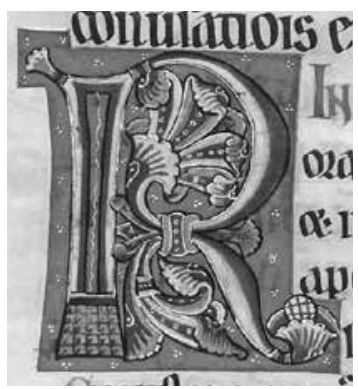

Missal Alc. 249, fl. 159

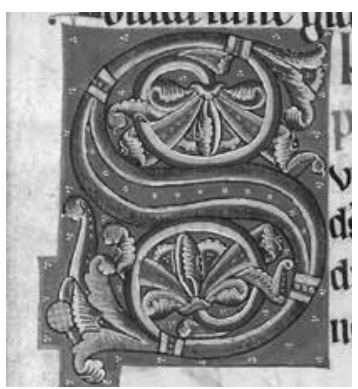

Missal Alc. 249, fl. 154

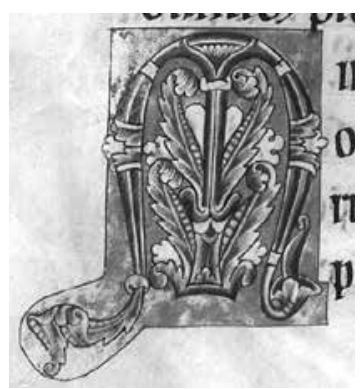

Missal Alc. 251, fl. 214v

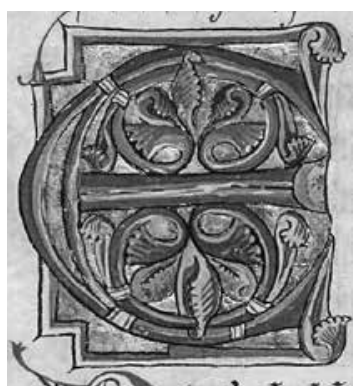

Missal Alc. 252, fl. 130v

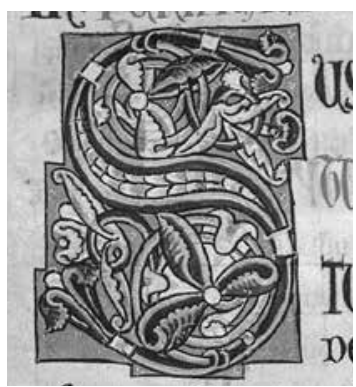

Missal Alc. 257, fl. 118

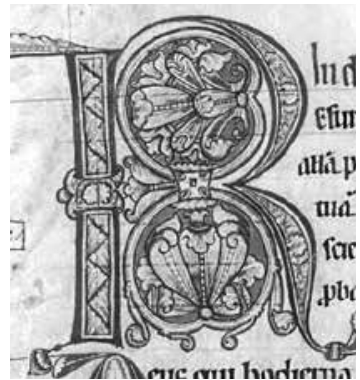

Missal Alc. 259, fl. 2v

44 Sobre as suas características formais, Adelaide Miranda refere proximidades com o Channel Style (Miranda 1996: 407). 
Estas semelhanças de ornamentação entre os manuscritos têm uma explicação: "Monasteries with large homemade libraries operate largely in a vacuum and tend to create ingrown families of books with similar script, ornament and display script that we can structure in time." (Stirnemann 2008: 156). E isto é bem visível nas características que as iniciais apresentam: os pequenos pontos brancos (por vezes em conjunto de três pontos) a preencher os fundos de cor e as iniciais, bem como o modo de caracterizar as folhagens no interior das iniciais mais pequenas, que marcam as secções internas, quer do Coletário-ritual, quer dos Missais.

Tabela 5. Iniciais de cor do Coletário-ritual Alc. 166 e do Missal Alc. 251

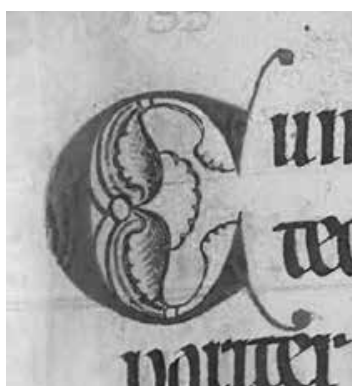

Coletário-ritual Alc. 166, fl. 55

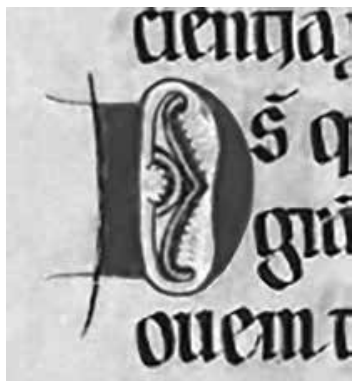

Missal Alc. 251, fl 233v

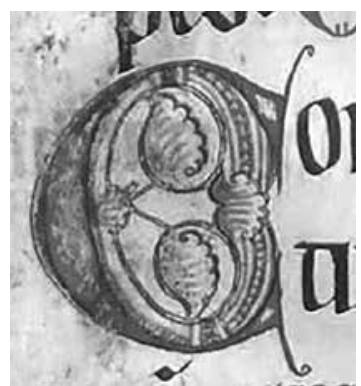

Missal Alc. 251, fl. 5

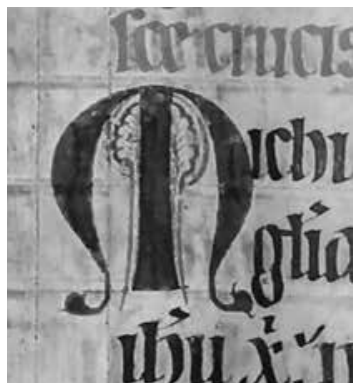

Coletário-ritual Alc. 166 fl. 77

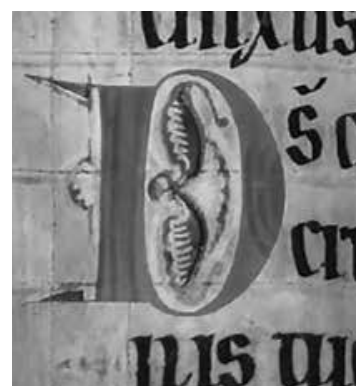

Coletário-ritual Alc. 166 fl. 77

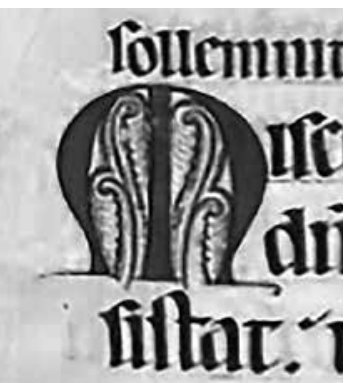

Missal Alc. 251, fl 67

\section{Notas finais}

Através da análise litúrgica de dois manuscritos, um Coletário-ritual e um Saltério-hinário e da sua contextualização, acreditamos ter conseguido comprovar que o scriptorium de Alcobaça produziu manuscritos iluminados no último quartel do séc. XII, entre 1175/85 e 1195. Antes de nós, Aires A. Nascimento já havia atestado, através da análise codicológica, em particular das encadernações, a produção de códices em Alcobaça nos finais do séc. XII (Nascimento $1984 \mathrm{e}$ Nascimento 1992b). Por outra via, que não a litúrgica, mas através de minuciosa análise paleográfica ao fundo documental do Mosteiro, António Joaquim R. 
Guerra já havia confirmado o funcionamento do scriptorium, ou seja, a produção de códices no último quartel do séc. XII (Guerra 2003). O intervalo cronológico apurado ajuda a repensar a questão da destruição causada pela incursão Almóada, por causa do funcionamento do scriptorium no referido período.

Desta problematização resultaram dados significativos para a questão da uniformidade litúrgica em Alcobaça, nomeadamente em relação à aplicação prática das decisões tomadas pelos Capítulos Gerais, decorrente quer da análise dos manuscritos, quer das suas adições. Por outro lado, confirmámos que a decoração iluminada destes dois manuscritos, mas em particular as iniciais folheadas que caracterizam o Coletário-ritual, influenciaram a produção iluminada posterior, nomeadamente os missais dos inícios do séc. XIII.

\section{Bibliografia}

AMOS, Thomas L. (1988). The Fundo Alcobaça of the Biblioteca Nacional, Lisbon, vol. I: Manuscripts 1-150. Collegeville, Minnesota: Hill Monastic Manuscript Library

AMOS, Thomas L. (1989). The Fundo Alcobaça of the Biblioteca Nacional, Lisbon, vol. II: Manuscripts 151- 301. Collegeville, Minnesota: Hill Monastic Manuscript Library

ANDRIEU, Michel (1931). Les ordines romani du haut moyen âge: Les manuscrits. Louvaina: Spicilegium sacrum Lovaniense.

BARREIRA, Catarina Fernandes, MELO, Maria João, ARAÚJO, Rita e CASANOVA, Conceição (2016). "Through the eyes of Science and Art: a fourteenth century winter Breviary from Alcobaça scriptorium”, Journal of Medieval Iberian Studies. Looking Ahead: New Approaches to Medieval Iberian Heritage, Routledge, Vol. 8, n.o 2, 252 - 282.

BARREIRA, Catarina Fernandes e RÊPAS, Luís Miguel (2016). "Um Ritual de Alcobaça em Salzedas", Invenire. Revista dos Bens Culturais da Igreja, Lisboa, n. ${ }^{\circ}$ 12, 28 - 35.

BARREIRA, Catarina Fernandes (2016a). "Questões em torno da unanimidade litúrgica no Mosteiro de Alcobaça - séculos XIII a XV”, Revista de História da Sociedade e da Cultura, Coimbra, n. ${ }^{\circ} 16,33-54$.

BARREIRA, Catarina Fernandes (2016b). "O quotidiano dos monges alcobacenses em dois manuscritos do século XV: o Ordinário do Ofício Divino Alc. 62 e o Livro de Usos Alc. 208”, Cadernos de Estudos Leirienses, n. ${ }^{\circ} 11,2016,329$ - 341.

BARREIRA, Catarina Fernandes (2015). "Questões em torno dos Ordinários do Oficio Divino de Alcobaça”, in Carla Varela Fernandes (coord.), Imagens e Liturgia na Idade Média. Lisboa: Secretariado Bens Culturais da Igreja, n. ${ }^{\circ} 4,131$ - 152.

BARROCA, Mário Jorge (2000). Epigrafia Medieval Portuguesa: 862 - 1422. Lisboa: Fundação Calouste Gulbenkian, $1^{\circ}$ vol.

BAURY, Ghislain (2010). "Une Bibliothèque Médiévale de Moniales Cisterciennes en Castille. Cañas et les membra disjecta de son missel”, Cîteaux. Commentarii cisterciensis, t. 61, fasc. 2-4, Scourmont, 141-183.

BELL, Nicolas (2013). "Liturgy" in Mette Birkedal Bruun (Edit.), The Cistercian Order, Cambridge: Cambridge University Press, 258 - 267. 
BENULIC, Barbara (2007). “Cistercian Legendarium (Alc.421) from Alcobaça: the problem of ornamented quire signatures”, Zbornik za umetnostno zgodovino vol. 43, 205-218.

BERMAN, Constance H. (2010). The Cistercian Evolution. The Invention of a Religious Order in Twelfth- Century Europe. Oxford: Penn.

BRAGANÇA, Joaquim Oliveira (2008). Liturgia e Espiritualidade na Idade Média. Lisboa: Universidade Católica Editora.

BRAGANÇA, Joaquim Oliveira (1984). Processional - Tropário de Alcobaça: Manuscrito 6207 da Biblioteca Nacional de Lisboa. Lisboa: Instituto Gregoriano de Lisboa.

CANIVEZ, Josephus Maria (1933/41). Statuta Capitulorum Generalium Ordinis Cisterciensis: ab anno 1116 ad annum 1786. Bibliothèque de la revue d'histoire ecclésiastique. Louvain: Bureaux de la Revue.

CASTRO, Rita, MELO, Maria João e MIRANDA, Adelaide (2014). “The Secrets behind the colour of the Book of Birds" in Adelaide Miranda e Alicia Miguélez (edit.) Portuguese Studies on Medieval Illuminated Manuscripts. Barcelona/Madrid, Brepols, 31-55.

CAVERO DOMINGUEZ, Gregoria (Coord.), FERNÁNDEZ GONZÁLEZ, Etelvina, GALVÁN FREILE e SUÁREZ GONZÀLEZ, Ana (2013). Tomás Becket y la Península Ibérica (1170 - 1230). León: Universidad de León e Instituto de Estudios Medievales.

CHOISSELET, Danièle e VERNET, Placide (1989). Les "Ecclesiastica officia" cisterciens du XIlème siècle. Reiningue : La Documentation Cistercienne, vol. 22.

CYRILLE, Vogel (1958). Le Pontifical Romano-germanique du Xe siècle. Éléments constitutifs avec indication des sections imprimées. Revue des Sciences Religieuses, tome 32, fascicule 2, 113-167.

COCHERIL, Maur (1966). Études sur le monachisme en Espagne et au Portugal. Paris/ Lisboa: Société d'éditions e Livraria Bertrand.

COSTA, Sara Figueiredo (2007). A Regra de S. Bento em Português. Lisboa: Edições Colibri e FCSH, Universidade Nova de Lisboa.

COUTINHO, Maria (2016). "Dispositivos visuais, ordenação e memorização. Breve comentário às iniciais, diagramas e ao loquela digitorum dos alc. 424 a 426” in Barreira, Catarina Fernandes (Coord.) Luz, Cor e Ouro. Estudos sobre manuscritos iluminados. Lisboa: Biblioteca Nacional de Portugal, 65-88.

DOLBEAU, François (1984). «Le Legendier d'Alcobaça», Analecta Bollandiana, 102, 263 $-296$.

FALMAGNE, Thomas (2012). Les Cisterciens et leurs bibliothèques. Troyes: Médiathèque du Grand Troyes

FERREIRA, Manuel Pedro (2013). "Dating a Fragment: A Cistercian Litany and its Historical Context," in Leandra Scappaticci (ed.), 'Quod ore cantas corde credas': Studi in onore di Giacomo Baroffio Dahnk. Roma: Libreria Editrice Vaticana, 70, 293-313.

FERREIRA, Manuel Pedro e ARAÚJO, Mara Fortu (2013). "Recitação do texto sacro: Claraval e Alcobaça” in José A. Carreiras (dir.), Mosteiros Cistercienses: História, Arte, Espiritualidade e Património. Alcobaça: Jorlis, Tomo II, 195-203.

FERREIRA, Manuel Pedro (2009). "Um fragmento de Alcobaça, o canto dos pregadores e os seus livros de coro na Biblioteca Nacional”, Actas do IV Congreso Internacional sobre El Cister en Portugal y en Galicia: Los Caminos de Santiago y La Vida Monástica Cisterciense, tomo II, Braga/Oseira, 732 - 753. 
FERREIRA, Manuel Pedro (2016). "Breves notas sobre o Iluminado 115” in Catarina Fernandes Barreira (Coord.) Luz, cor e ouro. Estudos sobre manuscritos iluminados. Lisboa: Biblioteca Nacional de Portugal, 319 - 326.

GOMES, Saul (2013a). “Abbés et vie régulière dans l’abbaye d'Alcobaça (Portugal) au Moyen Âge: un bilan” in Jean-François Cottier, Daniel-Odon Hurel, Benoît-Michel Tock, (coord.), Les personnes d'autorité en milieu régulier. Des origines de la vie régulière au XVIIIe siècle. Saint-Etienne, 137-150.

GOMES, Saul (2013b). "A vida litúrgica entre os monges de Alcobaça em meados de Quatrocentos: o Regimento dos Sacristães-Mores” in José A. Carreiras (dir.), Mosteiros Cistercienses: História, Arte, Espiritualidade e Património. Alcobaça: Jorlis, Tomo II, 423-448.

GOMES, Saul (2009). "Manuscritos medievais iluminados e fragmentos" in A. G. Maia do Amaral (coord.) Tesouros da Biblioteca Geral da Universidade de Coimbra, Coimbra, Imprensa da Universidade de Coimbra, 58.

GOMES, Saul (2002). "Entre memória e história: os primeiros tempos da Abadia de Santa Maria de Alcobaça (1152-1215)”, Revista de História da Sociedade e da Cultura, Coimbra, n. ${ }^{\circ}$ 2, 187-256.

GOMES, Saul (2000). "Revisitação a um velho tema: a fundação do Mosteiro de Alcobaça”, Cister. Espaços, Territórios, Paisagens. Atas do Colóquio Internacional. Lisboa: IPPAR, 27-72.

GOMES, Saul (1998). Visitações a Mosteiros Cistercienses em Portugal. Séculos XV e XVI. Lisboa: MC e IPPAR.

GUERRA, António Joaquim R. (2003). Os diplomas privados em Portugal dos séculos IX a XII. Lisboa: Centro de História.

GUSMÃO, Artur Nobre (1992). A Real Abadia de Alcobaça. Lisboa: Livros Horizonte.

JAMROZIAK, Emilia (2013). The Cistercian Order in Medieval Europe. 1090-1500. London: Routledge.

LEGENDRE, Olivier (2008). "Some Tools for Dating and Localizing Manuscripts”, Journal of the Early Book Society for the Study of Manuscripts and Printing History, n. ${ }^{\circ} 11$, Pace University Press, New York, 181-196.

LEROQUAIS, Victor (1934). Les Bréviaires manuscrits des bibliothèques publiques de France. Paris, vol. 1.

LEBIGUE, Jean-Baptiste (2014). "Rits et couleurs. Acronymie et chromonomie des calendriers liturgiques au Moyen Age” in Claudia Rabel (org.), Le manuscrit enluminé. Études réunies en hommage à Patricia Stirnemann. Paris: Leopard d'Or, 39-73.

MAITRE, Claire (2015). Le bréviaire cistercien Troyes, Bibliothèque Municipale, MS.2030. Fribourg, Academic Press.

MARQUES, Maria Alegria (2008). Estudos sobre a Ordem de Cister em Portugal. Coimbra: Edições Colibri e FLUC.

MATTOSO, José (2002). Obras Completas. Religião e Cultura na Idade Média Portuguesa. Lisboa: Círculo de Leitores

MATTOSO, José (2001). Obras Completas. Poderes Invisíveis. O Imaginário Medieval. Lisboa: Círculo de Leitores

MELO, Arnaldo Faria de Ataíde (1930-32). Inventário dos Códices Alcobacenses. Lisboa: Biblioteca Nacional, 5 vols. 
MIGUÉLEZ Cavero, ALICIA, Maria João, MIRANDA, Maria Adelaide, CASTRO, Rita e CASANOVA, Conceição (2016). "Beatus manuscripts under the microscope: the Alcobaça Beatus and the Iberian Cistercian tradition revisited”, Journal of Medieval Iberian Studies. Looking Ahead: New Approaches to Medieval Iberian Heritage, Routledge, Vol. 8, n. ${ }^{\circ} 2,217-251$.

MIRANDA, Adelaide (2015). "Bíblias Iluminadas no Portugal Medieval. Estudos” in Luís Correia de Sousa (coord.), Sacra Pagina. Textos e Imagens das Bíblias portáteis do século XIII pertencentes às coleções portuguesas. Lisboa: Paulus Editora, 31-36.

MIRANDA, Adelaide e MELO, Maria João (2014). "Secrets et découvertes en couleur” in Adelaide Miranda e Alicia Miguélez (edit.) Portuguese Studies on Medieval Illuminated Manuscripts. Barcelona/Madrid, Brepols, 1-29.

MIRANDA, Adelaide, LEMOS, Ana, CLARO, Ana, MIGUEL, Catarina e MELO, Maria João (2008). "A Cor na Iluminura Portuguesa uma abordagem interdisciplinar", Revista de História da Arte, Lisboa: Instituto de História da Arte n.o 5, 228-245.

MIRANDA, Adelaide (2007). "A Iluminura românica em Portugal” in Yarza Luaces (coord.), La miniatura medieval en la Peninsula Ibérica. Murcia, 375-418.

MIRANDA, Adelaide (2000). "Manuscritos bíblicos românicos de Santa Maria de Alcobaça”, Cister. Espaços, Territórios, Paisagens. Atas do Colóquio Internacional, 16-20 Junho 1998. Lisboa, Ministério da Cultura. IPPAR, 375-386.

MIRANDA, Adelaide (1996). A Iluminura Românica em Santa Cruz de Coimbra e Santa Maria de Alcobaça. Tese de Doutoramento, FCSH, UNL.

MUZERELLE, Denis (2013). "Lécriture» in Paul Géhin (dir.) Lire le manuscrit médiéval. Paris : Armand Colin, 85-121.

NASCIMENTO, Aires A. (2016). Os antigos códices de Lorvão. Balanço de pesquisa e recuperação de tradições. Penacova: Município de Penacova.

NASCIMENTO, Aires A. (2012). Ler contra o tempo. Condições dos textos na cultura portuguesa. Lisboa: Centro de Estudos Clássicos.

NASCIMENTO, Aires A. (2004), "Livros e tradições hispânicas no mosteiro cisterciense de Arouca”. Escritos dedicados a José María Fernández Catón. II, León, 1047-1048.

NASCIMENTO, Aires A. (1992a). "Legendarium Alcobacense”, Nos Confins da Idade Média. Lisboa, 149-150.

NASCIMENTO, Aires A. (1992b). "Le scriptorium d'Alcobaça: identité et corrélations”, Lusitânia Sacra, 2. a série, Tomo IV, 149-162.

NASCIMENTO, Aires A. (1991). "A experiência do livro no primitivo meio alcobacense", Atas do IX Centenário do Nascimento de S. Bernardo”. Braga: Universidade Católica e Câmara Municipal de Alcobaça, 121-145.

NASCIMENTO, Aires A. (1985). "Reliure médiévale du Fonds Alcobaça dans la Bibliothèque Nationale de Lisbonne”, Calames et Cahiers - Mélanges L. Gilissen, Bruxelas, 107-117.

NASCIMENTO, Aires A. e Diogo, António (1984). Encadernação Portuguesa Medieval. Alcobaça. Lisboa: Imprensa Nacional, Casa da Moeda.

NASCIMENTO, Aires A. (1979). “Em busca dos códices alcobacenses perdidos”, Didaskália, 9, 279-288. 
NASCIMENTO, Aires A. (1978). Inventário dos Códices Alcobacenses. Tomo VI (Índices). Lisboa: Biblioteca Nacional

PEIXEIRO, Horácio (2007). "As cores das imagens. A propósito da cor na iluminura alcobacense dos séculos XIV e XV”, Revista de História da Arte. Lisboa, n. ${ }^{\circ}$ 3, 103-129.

PEIXEIRO, Horácio (1991). “Um missal cisterciense iluminado (Alc. 26) e as representações da Virgem e de São Bernardo”, Atas do IX Centenário do nascimento de S. Bernardo. Universidade Católica e Câmara Municipal de Alcobaça, Braga/Alcobaça, 195-218.

PEIXEIRO, Horácio (1986) Missais iluminados séculos XIV e XV. Contribuição para o Estudo da Iluminura em Portugal. Lisboa: Tese mestrado, FCSH UNL.

PEREIRA, Isaías da Rosa (1996). "Dos livros e dos seus nomes. Bibliotecas litúrgicas medievais”, Signo. Revista de Historia de la Cultura Escrita, n. ${ }^{\circ}$ 3, Universidad de Alcalá de Henares, 133-161.

RÊPAS, Luís Miguel e Barreira, Catarina Fernandes (2016). "Place and Liturgy in an Illuminated Ritual from Santa Maria de Alcobaça” in Carla Varela Fernandes (coord.), Imagens e Liturgia na Idade Média. Lisboa: Secretariado para os Bens Culturais da Igreja, 211 -236.

SILVA, Manuel Teles da (1724). Colecçam dos documentos estatutos e memorias da Academia Real da Historia Portuguesa. Lisboa: Impresso na Oficina de Pascoal da Silva

SOUSA, Luís Correia (2016). In Principio. A Bíblia Medieval em diálogo com a pintura de Ilda David. Lisboa: BNP

SOUSA, Luís Correia (2015). Sacra Pagina. Textos e Imagens das Bíblias portáteis do século XIII pertencentes às coleções portuguesas. Lisboa: Editora Paulus.

STIRNEMANN, Patricia (2008). "Dating, Placing and Ilumination”, Journal of the Early Book Society for the Study of Manuscripts and Printing History, 11, Pace University Press, New York, 155-166.

SUÁREZ González, Ana (2016). "Silencio como en el claustro (entre libros cistercienses de los siglos XII y XIII” in Ramon Baldaquí Escandell (edi.) Lugares de Escritura: El Monasterio. Alacant: Publicaciones de la Universitat d'Alacant, 69-122.

SUÁREZ González, Ana (2012). “Notas “de viaje” sobre un libro viajero (Arouca, Museu de Arte Sacra, Livro L-Ms. 19), Rudesindus. Miscelánea de arte y cultura 8, 87-114.

SUÁREZ González, Ana (2005). "El libro en los claustros cistercienses (una aproximación c. 1140-1240)”, El Monacato en los Reinos de Léon y Castilla (siglos VII-XIII). Fundación Sánchez Albornoz, 264-325.

WADDELL, Crysogonus (2007). The primitive Cistercian Breviary. Fribourg, Academic Press.

WADDELL, Crysogonus (2002). Twelfth-century Statutes from the Cistercian General Chapter. Belgium: Cîteaux: Commentarii cistercienses.

WADDELL, Crysogonus (1984). The Twelfth-century Cistercian Hymnal. Kentucky: Cistercian Publications.

ZALUSKA, Yolanta e Damongeot, Marie-Françoise (2015). «Analyse liturgique du Lectionnaire de la messe (mss 177, fragment 1 , et 154) et de l'Epistolier (ms 156) conservés aux Archives départementales de la Dordogne», Manuscrits de Cadouin: Actes du colloque de Périgueux. Dordogne: Archives départementales de la Dordogne, 98-149. 
Anexo I

\begin{tabular}{|l|l|c|}
\hline \multicolumn{1}{|c|}{ Cota } & \multicolumn{1}{|c|}{ Tipologia } & Datação \\
\hline Alc. 11 & Saltério-hinário & XII \\
\hline Alc. 136 & Liber quaestionum, Isidorus Hispalensis & XII \\
\hline Alc. 143 & Miracula S. Thomae Cantuariensis & 1185 \\
\hline Alc. 152 & $\begin{array}{l}\text { Obras várias (sermões, epístolas, homilias, etc.), Bernardus } \\
\text { Claravallensis }\end{array}$ & XII \\
\hline Alc. 154 & De Arca Noe, Hugo de Sancto Victore & XII \\
\hline Alc. 157 & In duodecim Prophetas Minores glossa, Pseudo Hieronymus & XII \\
\hline Alc. 166 & Coletário-ritual & XII \\
\hline Alc. 231 & $\begin{array}{l}\text { (códice formado por dois códices distintos) } \\
\text { Martyrologium e Regra de S. Bento (até ao fl. 136) }\end{array}$ & XII \\
\hline Alc. 232 & Expositio de tabernaculo e Epistola, Petrus Cellensis & XII \\
\hline Alc. 238 & Opuscula, Vários autores & XII \\
\hline Alc. 248 & Opuscula, Vários autores & XII \\
\hline Alc. 332 & De Civitate Dei, Augustinus & XII \\
\hline Alc. 333 & Expositio in libris Regnum, Rabanus Maurus & XII \\
\hline Alc. 335 & Epistolae, Hieronymus & XII \\
\hline Alc. 336 & Expositio super Hieremiam profetam, Hieronymus & XII \\
\hline Alc. 357 & Sermones in Cantica Canticorum, Bernardus Claravallensis & XII \\
\hline Alc. 358 & Sermones de tempore, Bernardus Claravallensis & XII \\
\hline Alc. 367 & Opuscula, Autores vários & XII \\
\hline Alc. 418 a 422 & Legendarium per annum, Rogerius Fuldensis (?) & XII \\
\hline Alc. 423 & Expositio in Evangelium Lucae, Beda Venerabilis & XII \\
\hline Alc. 424 a 426 & Elementarium doctrinae erudimentum, Papias & XII \\
\hline Alc. 427 a 431 & Bíblia & XII \\
\hline & & \\
\hline
\end{tabular}

